\title{
New Directions in Russian Orthodox Church Architecture at the beginning of the Twentieth Century
}

\author{
William Craft Brumfield* \\ Tulane University \\ New Orleans, Louisiana, USA
}

Received 24.10.2015, received in revised form 16.11.2015, accepted 28.12.2015

\begin{abstract}
At the beginning of the 20th century certain influential voices in Russian architecture began to question the highly ornamental approach to church design that had reigned during the latter half of the 19th century. In the opinion of these architect-critics, the so-called Ostankinshchina style (named after the late 17th-century Church of the Trinity at Ostankino) seemed to deform the aesthetic purity of medieval Russian church architecture, even as it lessened the spiritual meaning of the church itself. In response, a number of architects, such as Aleksei Shchusev and Vladimir Pokrovskii, explored new paths in church design by combining a study of early medieval Russian forms with new technological methods.
\end{abstract}

Keywords: Russian church architecture, style moderne, "Ostankinshchina", Abramtsevo, Viktor Vasnetsov, Fedor Shekhtel, Aleksei Shchusev, Vladimir Pokrovskii.

DOI: 10.17516/1997-1370-2016-9-1-5-40.

Research area: culture studies.

The Russian artistic revival at the turn of the century is best known for its effect on secular culture in painting, music, and literature. Equally a part of the cultural life of the period was an architectural movement known as the "new style," or the "style moderne," which played a major role in transforming the built environment of Moscow and Petersburg during the final decades of Imperial Russia. Scholars in both Russia and the West have noted the antecedents of the style moderne in a native arts and crafts tradition, as well as its obvious links to European modernism in the form of art nouveau and the Vienna Secession ${ }^{1}$. The emphasis in this discussion has been on secular architecture. Yet during this same period there also occurred a renascence in church architecture that combined the plasticity of the new style and its use of advanced construction techniques with a rediscovery of the structural and decorative principles of medieval Russian religious architecture.

On first consideration it might seem paradoxical that so traditional a form as the structure of the Russian church should lend itself to the modernist movement. In fact the primary obstacle to a new interpretation of church architecture arose not from some inherently conservative principle within the design of the medieval Russian church (which had shown itself receptive to strikingly innovative forms

(C) Siberian Federal University. All rights reserved

* Corresponding author E-mail address: william.brumfield@gmail.com 
in both wood and masonry during the sixteenth and seventeenth centuries), but rather from the ponderous attempts in the nineteenth century to establish a national style in the building of churches after the decline of neoclassicism. The most noted proponent of this approach during the reign of Nicholas I was the architect Konstantin Ton, whose massive Church of Christ the Savior (1838-83; destroyed in the early 1930s) near the Prechistenka Quay in Moscow used what was considered to be a Russo-Byzantine style to reestablish the purity and orthodoxy of Russian church architecture (Fig. 1) ${ }^{2}$.

Although subsequent exercises in the national style were rarely so expressive of official ideology, the attempt to rephrase the essence of national identity in the design of churches led either to a predictable repetition of the RussoByzantine elements or to an encrustation of church facades with decorative motifs reproduced in archeological precision from the highly ornamental churches of late seventeenth century Muscovy. So firmly was this ornamentation identified with an authentically Russian style by Ivan Ropet, Viktor Hartmann, Vladimir Shervud, Nikolai Sultanov and others during the latter part of the nineteenth century, that its primary function shifted from the decoration of churches to the secular structures designed to meet the increasingly diverse needs of Russia's expanding cities during the latter half of the century. This "pseudo- Russian" or Russian Revival style was especially evident in Moscow, not only in major buildings such as the Historical Museum (Shervud), the Technological Museum (Ippolit Monighetti), and the Moscow City Duma (Dmitrii Chichagov), but also in the design of numerous commercial and housing structures.

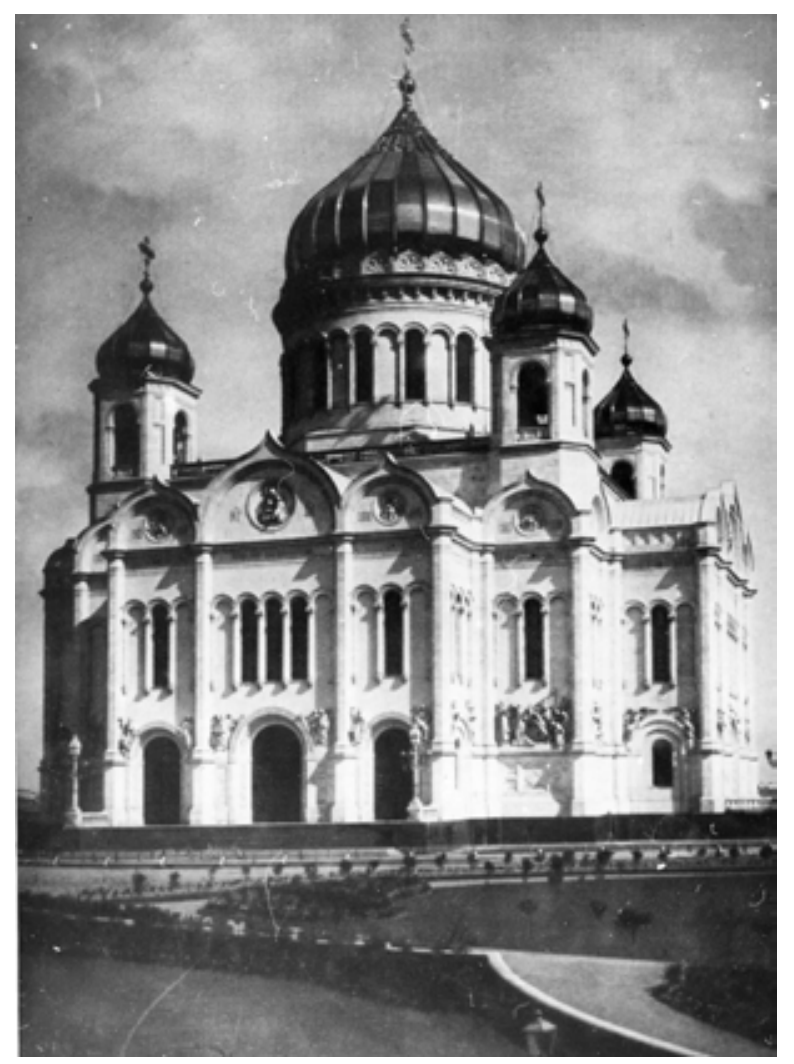

Fig. 1. Moscow. Cathedral of Christ the Savior. 1838-83. Architect: Konstantin Ton. Southeast view 
Despite this semiotic transposition of "national" stylistic devices from religious to secular architecture, the use of architectural symbolism to a two-dimensional text (to be read on the surface of a building, independently of the interior structure) had little to do with essence of medieval Russian church architecture. Despite the impressive scale and decoration of major churches constructed in the last three decades of the nineteenth century, the repetitive application of superficial detail often produced churches marked by a loss of the proportions and structural harmony characteristic of their medieval antecedants.

The impasse created by persistent attempts to adapt church design to a concept of national style (whether initiated from above or supported by "democratic" voices such as the influential art critic Vasilii Stasov) led at the beginning of the century to open criticism of attitudes underlying the design, building, and decoration of Orthodox churches. One of the most explicit attacks on the current order appeared in a presentation at the Fourth Congress of Russian Architects, held at the Imperial Academy of Arts in January 1911. Entitled "Russian Church Art and its Contemporary Goals," the lecture represented the views not of a disgruntled outsider, but of one who stood at the very center of the official system - Andrei Aplaksin, an architect attached to the Petersburg Eparchy3. Furthermore, the journal Zodchii, the publication of the Imperial Petersburg Society ofArchitects, noted at the end of its report on the lecture that the audience included Grand Duke Petr Nikolaevich, whose presence implies a degree of official approbation for Aplaksin's views ${ }^{4}$.

After presenting a survey of the development of Russian church architecture, from its antecedents in Kiev and Vladimir to its imitation of Western forms during the eighteenth century, Aplaksin places the decline at a period of general stagnation in European architecture following the final flowering of neoclassicism. At this point Russian policy on church construction adopted what Aplaksin calls a "false path" [lozhnji shag] by implementing in 1841 an official preference for the "ancient Byzantine style" ["drevnii vizantiiskii stil"'] in the building and repair of churches (as stipulated in current article 101 of the building code) $)^{5}$ ["lozhnij shag v vide uzakonennogo (25 marta 1841 g) trebovaniia pri postroike i remonte tserkvei "predpochtitel'no drevnii vizantiiskii stil”" (sovremennaia st. 101 ust. stroit.) "] This legislation of aesthetic policy not only produced artificial and improper constraints (according to Aplaksin), but also had a further, unforseen effect: "As a counterweight [to the "Byzantine" style] there began a search for an individual style, which was fabricated under the portentous name "Russian" and characterized by coxcomb ornaments, onion domes, and kokoshniki. Thus in church construction, which was especially intensive at this time, there appeared two approaches: the quasi-Byzantine sanctioned by law - and the quasi-Russian, otherwise known as Ostankovshchina [after the highly-decorated late seventeenth-century Church of the Trinity at Ostankino]."“ ["Kak protivoves, nachalis' poiski sobstvennogo stilia, kotoryi byl sfabrikovan pod gromkim imenem "russkogo" $i$ kharakterizovalsia petushkami s grebeshkami $i$ lukovichkami s kokoshnikami. Takim obrazom $v$ tserkovnom stroitel'stve, kotoroe v etot period stalo osobenno intensivnym, poluchilos' dva nachala: quasi-vizantiiskoe - osnovannoe na zakone $i$ quasi-russkoe, imenouemoe inache “ostankovshchinoi." “]

Aplaksin's criticism of contemporary church construction and its decoration (including the iconostasis) is unrelenting: "The contemporary church built in the above manner is, from an artistic point of view, a combination of lack of talent, lack of taste, and commercialism ...." ["Postroennyi 
takim obrazom sovremennyi khram iavliaetsia, s tochki zreniia iskusstva, sovmestitel'stvom bezdarnosti, bezvkusiia i rynka, kakogo ne bylo ni v odnu iz predshestvuiushchikh epokh.'] The last factor is of particular interest as an indication of the extent to which commercial, secular building practices had asserted a logic of their own, quite independent of both the ideology of the Russian Style and of the traditions of church architecture. For Aplaksin the lack of inspiration in contemporary church architecture derived from three sources: the building code, society, and the architect. The articles of the building code legislated a style and placed further restrictions on any deviation from an officially approved plan; society and church donors were ignorant of aesthetic concerns beyond a desire for the lavish display of their donation; and architects - the most guilty - thought only of the external appearance of the church, decorated in a manner that showed little understanding of the historical prototypes that were so carelessly imitated ${ }^{7}$.

Aplaksin saw cause for optimism in the methodical study of medieval monuments under the auspices of the Academy of Arts and the Archeological Commission, although the completion of this project was still remote in view of the great number of existing Russian churches: 51,413 as of 1907 , with an additional 20,113 chapels $^{8}$. Aplaksin's enthusiam for an informed survey of church architecture was expressed in his appeal to architects - as well as the representative of the Imperial court - to support the "photography, research, and measurement" of these monuments; but it is unlikely that such an academic enterprise would have served, in actual practice, as an effective stimulus for the aesthetic revival of church design ${ }^{9}$.

In fact, events had already overtaken Aplaksin's criticisms. Despite his knowledgeable assessment of the general level of Orthodox church architecture during the past century, the renewed appreciation of early medieval churches, reflected in Russian art criticism at the turn of the century, influenced a number of innovative church designs by 1911. To be sure, many of these designs lay beyond the purview of official Orthodoxy. It is no accident that the most significant work in this architectural revival occurred after 1905, during the rapid surge of church construction for Old Believer communities in Moscow and Petersburg. In addition to the Old Believer churches, there were distinctive examples of the new style supported by private foundations or individuals, with no direct obligation to the local parish. Each of these categories involved some of the best architects of the period, whose church designs whether projected or built - were given extensive publicity in the architectural press.

However, the earliest example of the aesthetic revival in Russian church architecture was created not by professional architects, but by a community of artists at Savva Mamontov's estate of Abramtsevo. Much has been written about the genesis and design of the small Church of the Savior "Nerukotvornyi," both in the memoirs of Natalia Polenova - daughter of the painter Vasilii Polenov - as well as in Soviet scholarship $^{10}$. The church, built in 1881-82 and dedicated to the Mandylion icon, was not solely an aesthetic object, but a functioning place of worship for those who lived on the estate and in the surrounding area. Yet it would eventually be seen as an architectural landmark that demonstrated the relevance of medieval structure and form to the modern style.

The sources of inspiration for the design have been identified as the Church of the Transfiguration of the Savior on the Nereditsa, (whose "unrestored" appearance at that time was considerably different from its present form) and to various churches of a much later period in the Rostov area ${ }^{11}$. The original sketches for the building were largely the work of Vasilii Polenov, 
one of the earliest members of the Abramtsevo circle; and as published by Natalia Polenova, these sketches bear a clear resemblance to the Nereditsa church. Yet they also contain other features, unrelated to Novgorod architecture, that were to be retained in Viktor Vasnetsov's final version of the building, which extended the variety of sources still further. (Fig. 2) In

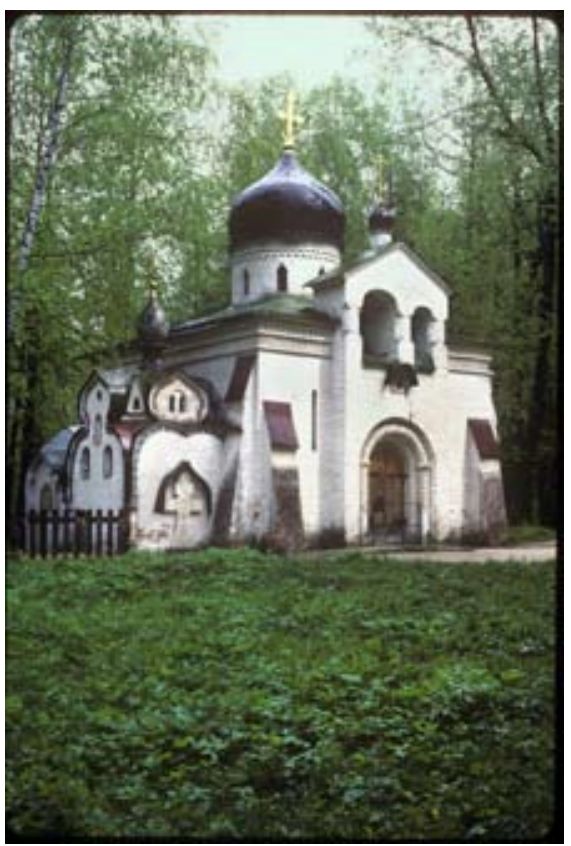

a

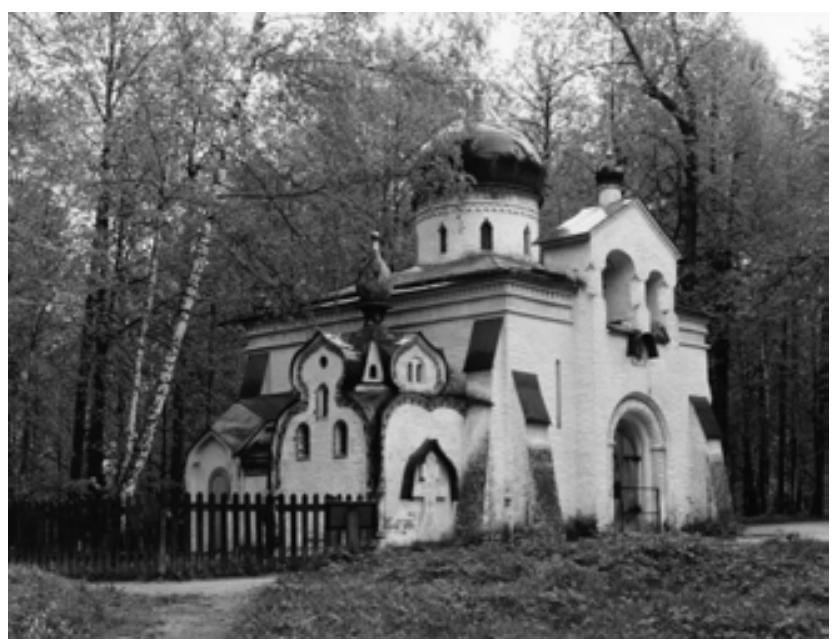

b

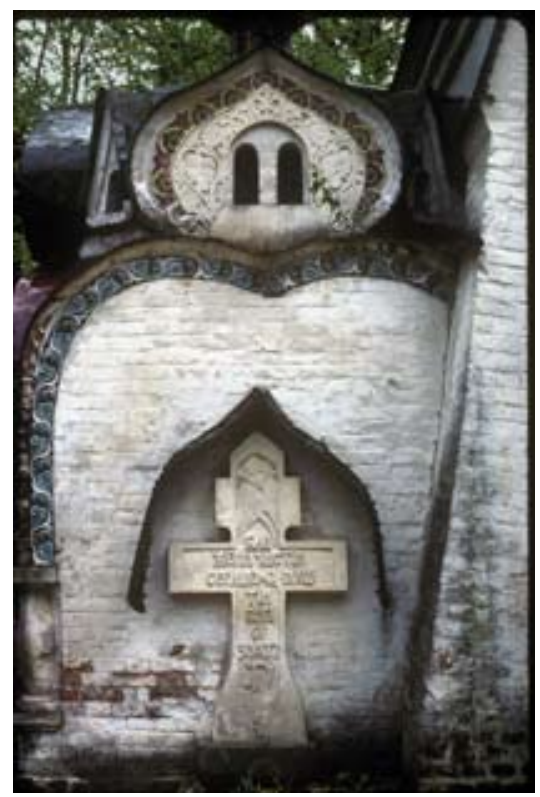

$\mathrm{c}$

Fig. 2. Abramtsevo. Church of the Icon of the Savior. 1881-82. Architect: Viktor Vasnetsov. Northwest view (a); Northwest view (b); Northwest corner. Mamontov family burial chapel. (c) Photo: William Brumfield 
fact the church was a mixture of elements that represented no one particular style, least of all the seventeenth-century stylization typical of the pseudo-Russian school.

It is significant that both Polenov and Vasnetsov were painters who specialized in evoking scenes from the Russian past, and who neither required nor used advanced construction methods at Abramtsevo. The nature of their innovation lay not in technical developments or a new application of the historical styles used by professional architects, but in an interpretation of structure that emphasized the interrelatedness of component parts rather than the decoration of the facade. As Elena Borisova has noted in reference to the Abramtsevo church: "The main thing, perhaps, is that precisely in architectural creativity could the artists satisfy that tendency to the plastic, which professional architects felt somewhat later, and for which painters had still not found a place on their canvases." ${ }^{\prime 2}$ [No samoe glavnoe sostoit, pozhalui, $v$ tom, chto imenno $v$ arkhitekturnom tvorchestve khudozhniki mogli udovletvorit' tu tiagu k plasticheskomy, kotoruiu professional'nye zodchie oshchutili neskol'ko pozzhe i kotoroi khudozhniki-zhivopistsy eshche ne nakhodili mesta $v$ svoikh polotnakh.]

This "tendency to the plastic" [tiaga $k$ plasticheskomu] is noticeable both in the shaping of the structure and the details of the exterior. There are few literal "quotes" in the design of the facades of the Abramtsevo church. The exaggerated contours, the large curved segmented window on the south wall, and the carved limestone details (Fig. 3) bear little relation to an archeologically precise reproduction of the

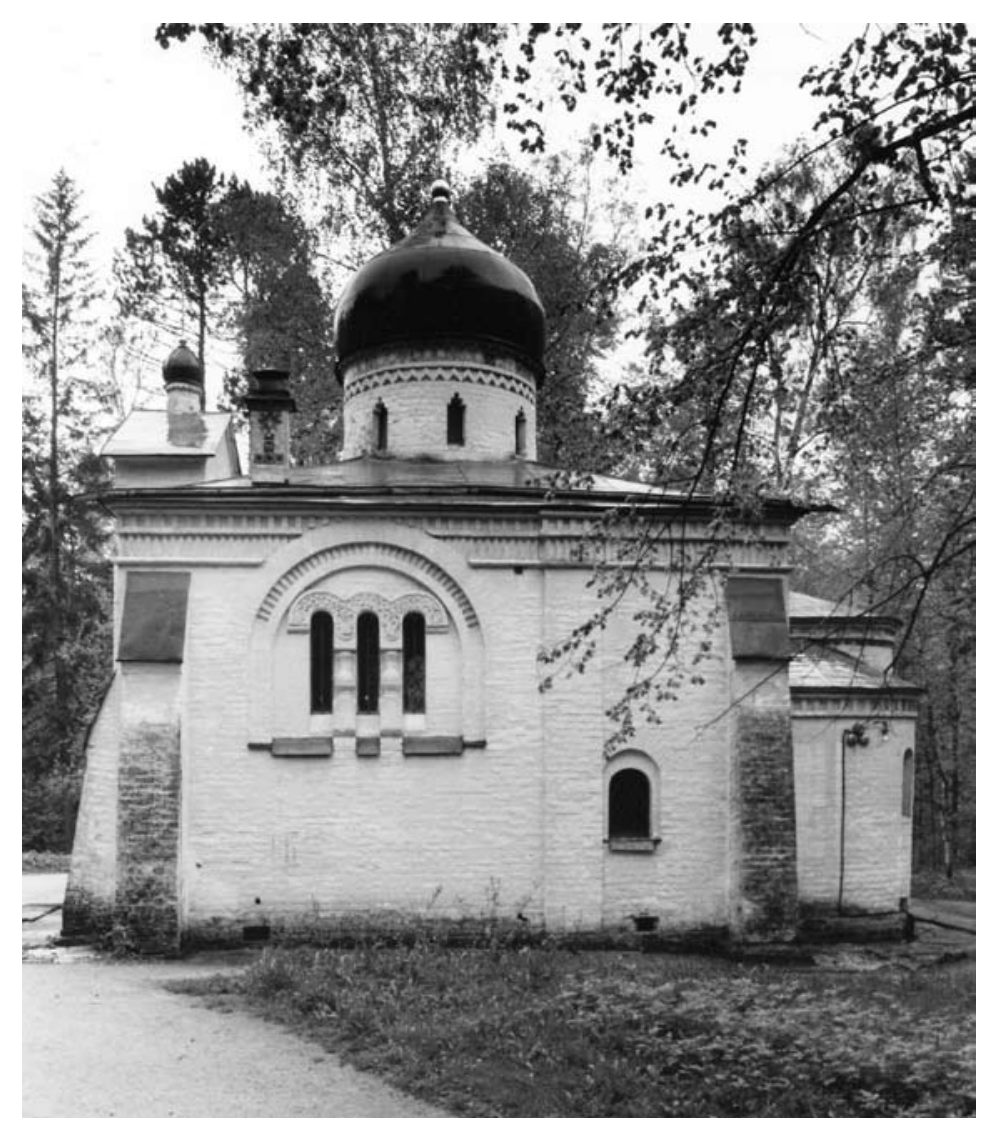

Fig. 3. Abramtsevo. Church of the Icon of the Savior. South view. Photo: William Brumfield 
small churches of Novgorod mentioned above. The similarity is structural, and it appears without the decorative overlay that characterized the Russian "national" style in both church and secular architecture. Yet this search for the sense of structure rather than the reproduction of style was either ignored or misunderstood by architects and critics at the end of the nineteenth century. Writing to Elena Polenova in January 1895, Vasilii Stasov referred to the Abramtsevo church dismissively as "without creativity," and particularly criticized its lack of resemblance to twelfth-century Russian churches, which, he was led to believe, served as its model ${ }^{13}$.

The free-style approach to medieval architecture represented at Abramtsevo had no immediate effect on the design of churches in Russia. Indeed, it was not until the success of Viktor Vasnetsov's main facade for the Tretiakov Gallery, completed by 1905, that the Abramtsevo church itself received extensive publicity in the architectural press ${ }^{14}$. Throughout the final decades of the nineteenth century Zodchii continued to reproduce elevations and details of seventeenth-century churches, while the design of contemporary churches followed the dichotomy defined by Aplaksin: either quasi-Byzantine or quasi-Russian (i. e. "Ostankovshchina").

At the turn of the century, Fedor Shekhtel applied his considerable talents to ecclesiastical architecture, although his church designs of this period - both built and projected - conformed to the accepted styles, as in his Byzantine Church of the Transfiguration of the Savior at IvanovoVoznesensk (1898), which closely resembles the work of Andrei Huhn during the 1880s. Decorative Russian motifs appeared in the large chapel that Shekhtel built in 1899 adjacent to Moscow's Church of Vasilii Kessariiskii to commemorate the wedding of Nicholas and Alexandra. A much freer interpretation of the Byzantine style characterized his 1899 project - unrealized - for a large cathedral at the Monastery of the Nativity in Moscow $^{15}$. Shekhtel also redesigned the interiors of a number of churches during the late 1890 s, all in the traditional manner; but his most ingenious work in the design of space for worship occurred in the chapel that he incorporated within one of the major monuments of the style moderne in Moscow: the house of Stepan Pavlovich Riabushinskii (1900-02).

Although the Riabushinskii chapel exists entirely within the structure of the house, and thus has no part in a survey of church architecture, it is of interest that this exquisite domed interior was built for the private use of a merchant who subscribed to the Old Belief. Much that is innovative in Russian church architecture at the beginning of the twentieth century can be attributed to Old Believer communities, whose release from legal restrictions after 1905 stimulated a surge of church construction in Moscow and, to a lesser extent, in Petersburg. Despite the paradox of architectural innovation in churches which drew their support primarily from a merchant class known for its conservative social and cultural attitudes, it should be noted that certain scions of prominent Old Believer families actively sought innovative forms in the arts as a form of cultural identity ${ }^{16}$.

This phenomenon was reinforced by an understandable reluctance among Old Believer communities to follow the established styles of Orthodox church architecture during the preceding decades, both for reasons of cost and for differences in religious observances. Denied for centuries the ability freely to build places of worship (with the exception of a brief period during the reign of Catherine the Great), the Old Believers communities frequently turned to an adaptation of simple medieval forms antedating the great Schism of the seventeenth century - in other words, to the churches of Novgorod and Pskov that had inspired the Abramtsevo artists. 
The most accomplished work of the period in Moscow belongs to Ilia Bondarenko, who designed at least three Old Believer churches: one for the Maritime Community (Pomorskoe soglasie) on Tokmakov Lane (1907-08); another for the Intercession-Dormition Community on Gavrikov Lane (1911); and a third for the Nikola-Rogozh Community (1912). The church for the Pomortsy, dedicated to the Resurrection of Christ and the Intercession of the Mother of God, is the most curious of the three in design, with a pitched roof sheltering a bell cote on truncated pillars over the narthex. The basic form derives from wooden architecture of the far north, but Bondarenko's interpretation is highly idiosyncratic. The gable beneath the tower roof portrayed an icon carried by two angels in a mosaic or ceramic tiles, whose colorful forms were set on a background of high-quality pressed brick for the main facade. By applying modern techniques such as reinforced concrete for the vaulting, Bondarenko created an unobstructed interior space capable of accommodating 500 people, in addition to the narthex with separate coat rooms for men and women. A lower floor, or half-basement, contained five meeting rooms as well as service space for the maintenance and heating of the structure.

The interior was decorated with an elaborately carved iconostasis containing a number of valuable icons; yet the iconostasis, separating the altar space from the congregation in Orthodox usage, served a very different function in this sectarian church for bespopovtsy, who had no priest or altar. All ritualistic functions occurred in view of the worshippers, while the space behind the iconostasis was used as a council room for the community elders. Additional icons, much revered by Old Believer communities, were placed along the walls. The functional, relatively austere design of the interior, illuminated by large tinted windows, resembled more closely the simplicity of a Protestant meeting house, than the usual Orthodox church with frescoes and narrow windows. Nonetheless, contemporary accounts note the considerable effort applied to the furnishing of this church - now vandalized almost beyond repair - in antiqued bronze, silk, carved stained oak, and wrought iron.

The most distinctive part of Bondarenko's church for the Pomortsy - and the one part still capable of restoration - is the exterior. (Fig. 4) In the curious distortion of historical perspective characteristic of nineteenth-century church architecture, the adaptation of architectural styles prior to the seventeenth century actually seemed innovative, as is evident in the concluding comments in Zodchii's report on the church:

"The style of the church is a departure from the usual type, and basically acquires the traits of northern architecture, primarily of the Novgorod-Pskov churches, while the models for the iconstasis and furnishings are derived from some of the most ancient objects of Russian art."17

[Stil' khrama - otstupulenie ot obychnogo tipa $i$ v osnovu vziaty cherty severnogo zodchestva, preimushchestvenno Novgorodsko-Pskovskikh khramov, prichem dlia ikonostasa i utvari obraztsami sluzhili naibolee drevnie predmety russkogo iskusstva.]

Bondarenko's Church of the Intercession (1911), for the Intercession-Dormition Community on Gavrikov Lane, although still quite free in interpreting the Novgorod style, was more traditional in its use of the cross- inscribed plan, with heavily-sculpted gables and one dome over the center of the structure. (Fig. 5) Like the church for the Pomortsy, the Intercession-Dormition church contained a narthex (not common in Orthodox architecture), to which Bondarenko attached a belltower of unusual configuration supporting an elongated "tent" roof. Both the main cupola and the tower were surfaced with gilded ceramic tile that endowed the exterior 


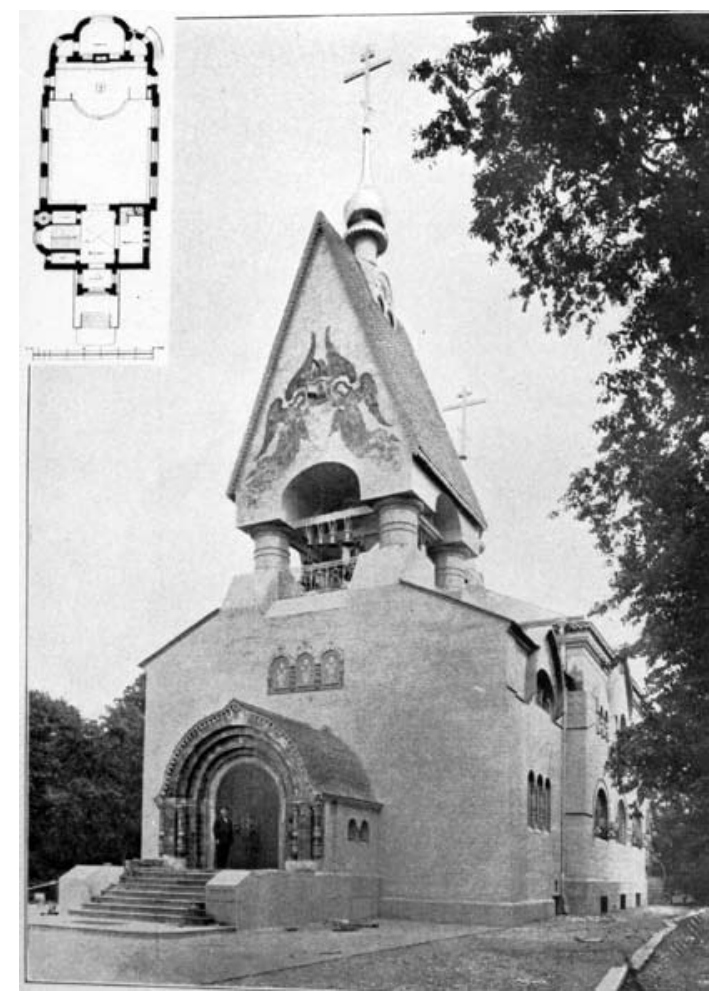

a

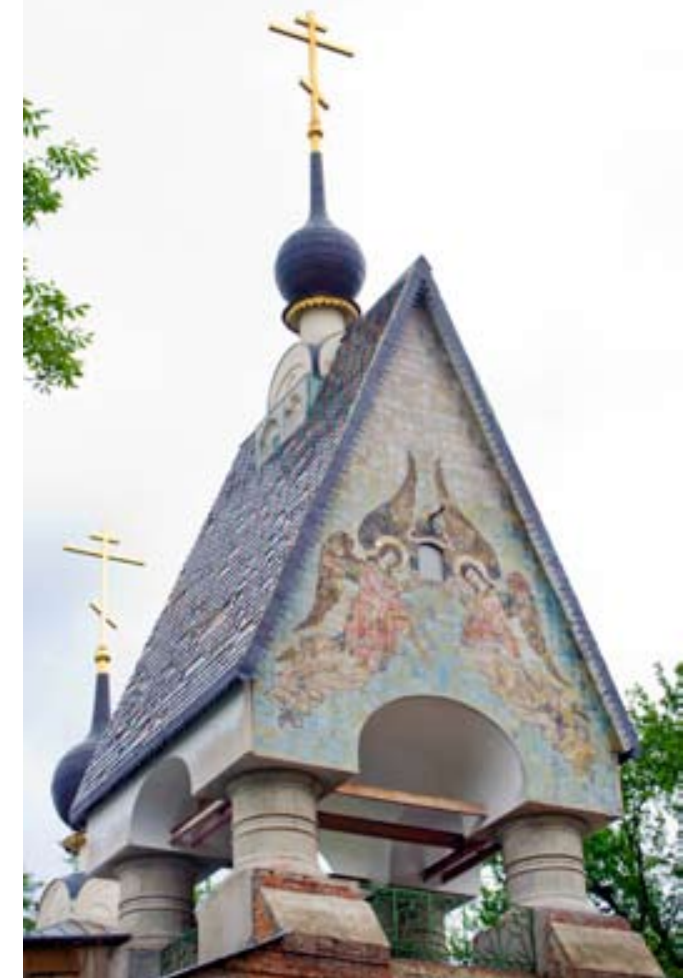

b

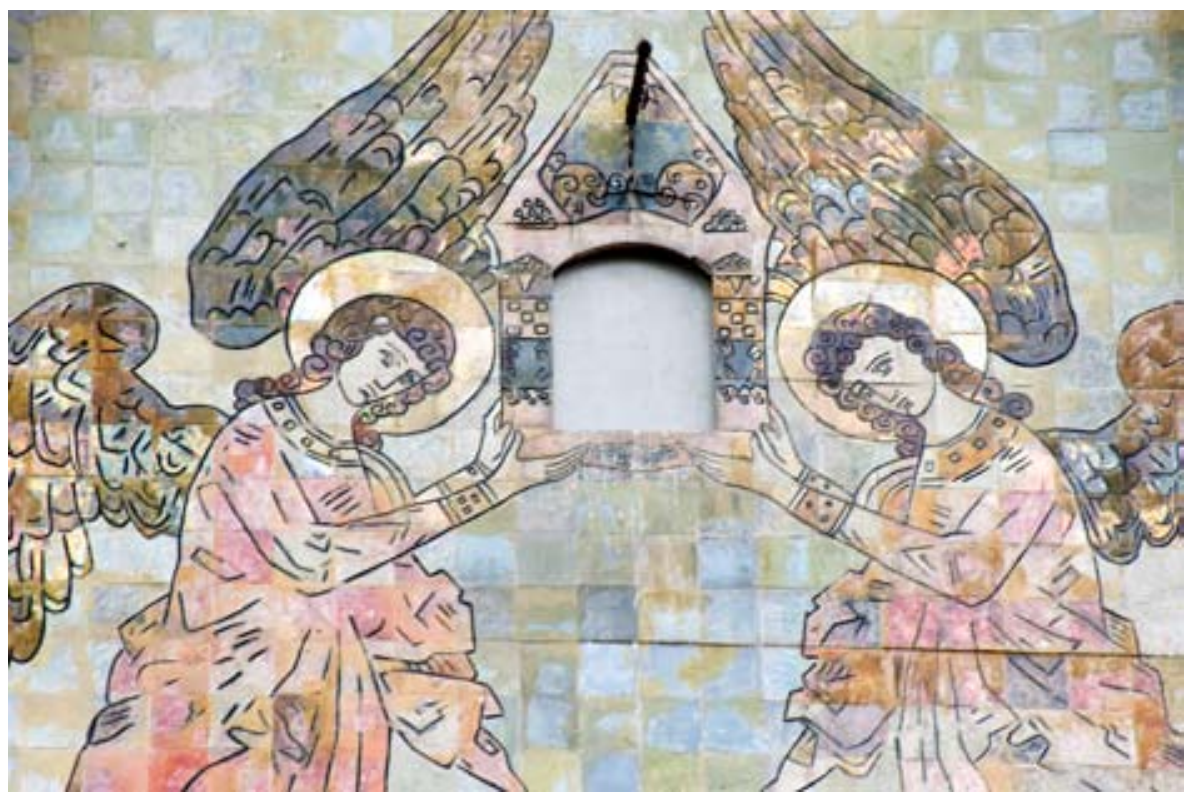

c

Fig. 4. Moscow. Church of the Resurrection of Christ on Tokmakov Lane. 1907-08. Architect: Ilia Bondarenko. West view. Ezhegodnik Obshchestva arkhitektorov-khudozhnikov, 1908 (a); Bell cote, west view. Photo: William Brumfield (b); Bell cote, ceramic facade (angels holding icon frame). Photo: William Brumfield (c) 


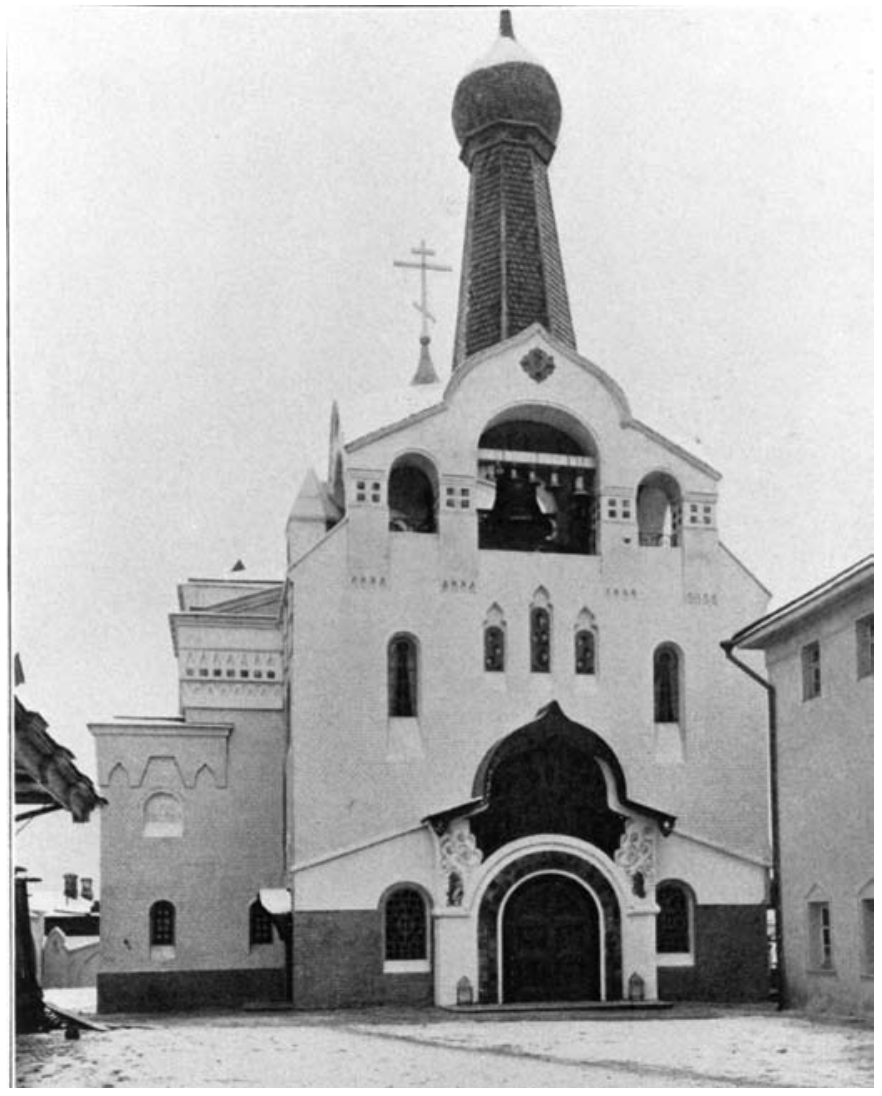

Fig. 5. Moscow. Church of the Intercession on Gavrikov Lane. 1911. Architect: Ilia Bondarenko. West view. Ezhegodnik Moskovskogo arkhitekturnogo obshchestva, 1910-11

with a particularly brilliant effect. Each of the main structural elements can be traced to motifs of the northern style in both wood and masonry, yet Bondarenko's combination represents an emphatic departure from accepted practice in church design - a departure that in some ways reflected the differences between official Orthodoxy and the Old Belief.

For all of the traditional motifs incorporated within the Intercession-Dormition church, the structure displayed a number of features common to the new style, not only in its emphasis on the plasticity of form (particularly in the contoured outlines of the walls, of cream-colored pressed brick), but also in such advanced construction techniques as its use of ferro-concrete for the walls, the vaulting, and even the drum and cupola $^{18}$. Bondarenko used ferro-concrete still more extensively in the third of his Old Believer churches in Moscow, the Church of St. Nicholas the Wonder-Worker, for the Nikola-Rogozhsksaia community (1912; at Malaia Andronovka and Third Rogozhskaia Streets). This pentacupolar structure, combining elements of both sixteenthcentury Muscovite and Novgorod architecture, was the largest and most complex design of the three churches, with numerous cupolas and three spires over the entrance portal, whose facade portrayed two angels holding an icon. The repetition of this latter motif in Old Believer churches testifies to the reverence extended to the old, pre-reform religious images. Like the Intercession-Dormition church, the NikolaRogozhskaia church included a large bell tower 
with tent roof, although the latter tower was a free standing structure linked to the main structure by a gallery at the northwest corner ${ }^{19}$.

Among other Old Believer churches in Moscow that applied medieval motifs in modern form, one of the most sensitive interpretations was the Church of the Intercession of the Mother of God, built in 1908-10 for the Ostozhenka Community with funds provided by the Riabushinskii brothers. The architects of the church, V. D. Adamovich and V. M. Maiat, are known primarily for their prolific contributionto the neoclassical revival in Moscow, including the Vtorov mansion (1913; now Spaso House, the residence of the American ambassador). One of the major characteristics of the development of the architectural profession in Russia during the nineteenth century was the capability to design in widely varying styles, often for religious as well as secular projects; and as thorough professionals, Adamovich and Maiat had little difficulty in adapting the architecture of fifteenth-century Pskov to the requirements of the Ostozhenka Community. (Figs. 6,7) Of all the medieval stylizations in Moscow's Old Believer churches, this was the most faithful in an "archeological" sense, including the begunets and porebrik decorative patterns in brick and the use of a thin layer of white stucco over the brick facade. There were minor concessions to Old Believer custom, such as the narthex containing a vestibule and separate cloakrooms for men and women, and an open bell gable - also in the Pskov style - above the entrance to the narthex ${ }^{20}$.

In total the various Old Believer communities constructed at least fifteen free-

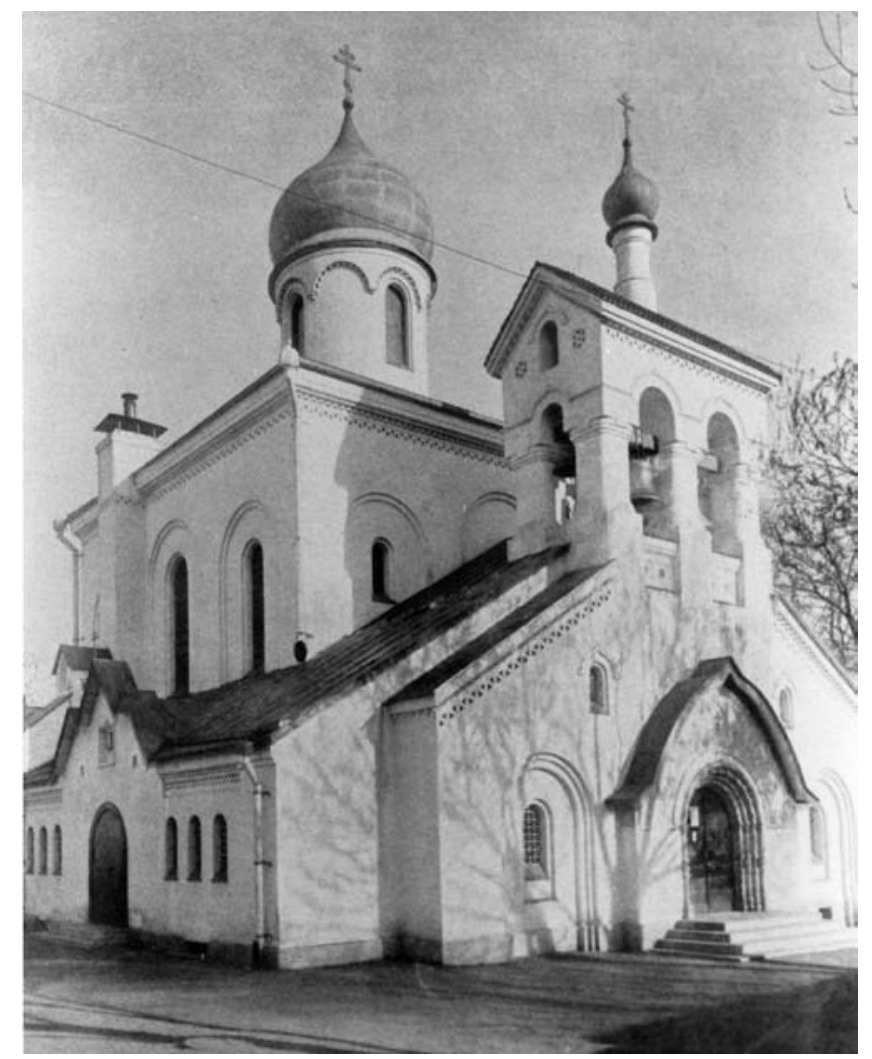

Fig. 6. Moscow. Church of the Intercession in Ostozhenka. 1908-10. Architects: V. D. Adamovich, V. M. Maiat. Ezhegodnik Moskovskogo arkhitekturnogo obshchestva, 1910-11 


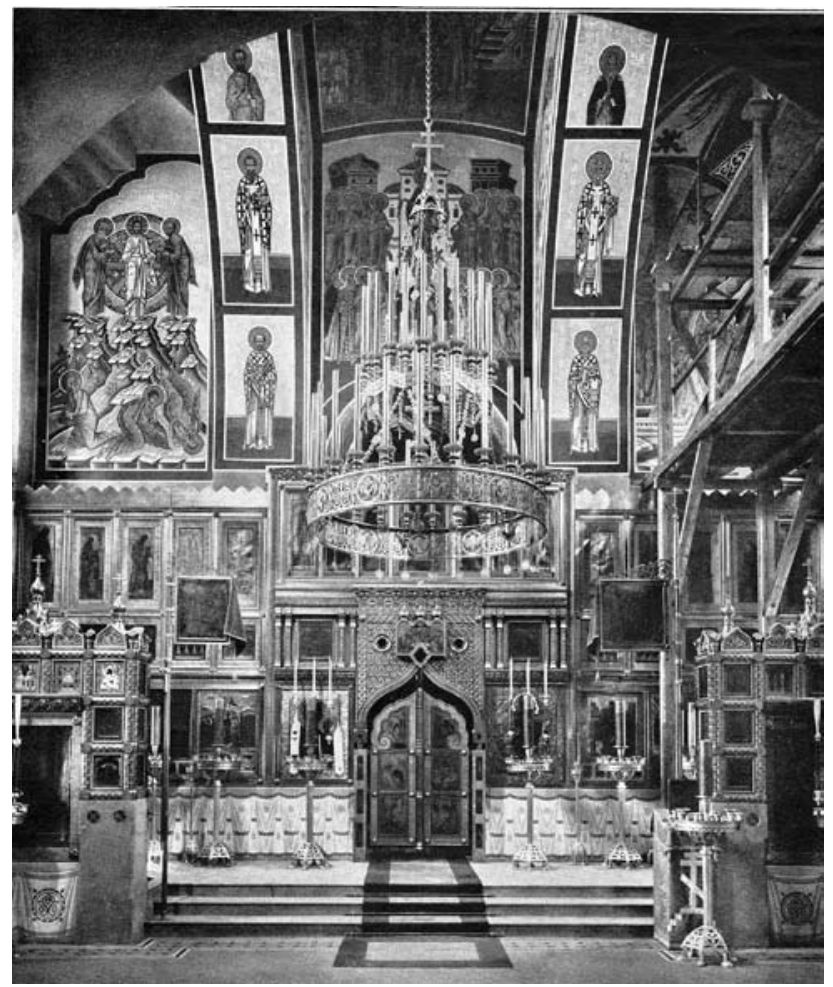

Fig. 7. Moscow. Church of the Intercession in Ostozhenka. Interior, view east toward iconostasis. Ezhegodnik Moskovskogo arkhitekturnogo obshchestva, 1910-11

standing churches in Moscow between the beginning of the century and the Revolution, including one more by Adamovich in 1915. The four described above gained the most attention from the contemporary architectural press, which viewed them as models of the new style in church architecture. Yet sectarianism or religious dissent were not prerequisites for artistic inspiration, nor was the design of Russian Orthodox churches hopelessly entangled in bureaucratic regulations and a general mediocrity of taste. Both of these impediments did indeed exist, as Aplaksin's lecture indicated; but the new understanding of medieval Russian monuments had created opportunities for something greater than an imitation of seventeenth-century forms. By the turn of the century, religious architecture had become an essential part of the curriculum in leading architectural schools, such as Petersburg's Institute of Civil Engineering, where students graduating from the architecture course had to submit two diploma projects: one in secular and one in church architecture.

Under these circumstances, it could be expected that church design would eventually attract the attention of some of the most talented architects of the new generation, including a number who later attained distinction in the resolutely secular environment of Soviet architecture. Within this group, no one approached the revival of church architecture with a greater understanding of the harmony between medieval forms and the new aesthetic than did Aleksei Shchusev (1873-1949). Shchusev's career has been so closely linked with the vicissitudes of Soviet architectural policy (to which he adapted with astonishing facility), that it is necessary to 
stress the central role of church architecture in his pre-revolutionary work and writings.

Educated at the Imperial Academy of Arts, from which he graduated in 1897, Shchusev rapidly assumed a prominent position in the Petersburg Society of Architects, before moving his practice to Moscow. At a meeting of the Petersburg Society in 1905, he delivered a talk entitled "Thoughts on creative freedom in religious architecture" (subsequently published in Zodchii), in which he roundly condemned the sterility and tasteless brilliance of official Orthodox church design in terms that anticipate Aplaksin's lecture. In fact the two architects have essentially the same objections: the unwarranted interference in the design process by clergy, donors, and official institutions; and the inability of architects themselves to devise anything more than a crude, uninformed imitation of historical prototypes.

It is on the latter point that Shchusev began to define the principles necessary to counter the reigning mediocrity and regain the vitality of traditional Russian architecture. In his view the worst offence of recent church architecture was not simply the haphazard imitation of assorted medieval forms:

No, architects go further and try to correct them [the old forms], to endow them with socalled proportions in the Franco-Italian manner, which in the end destroys even the typicality of old forms, and gives us not churches conducive to prayer by their forms and interior furnishing, but simply some sort of dance or concert hall, loudly and crudely painted and gilded. With their false grandeur and glitter, such creations bring joy to the clergy and parishoners, and instead of developing the taste of the simple folk, impart to them a love for all that glitters, but not for the $\operatorname{artistic}^{21}$.

[k sozhaleniiu, arkhitektora smotriat na tserkovnuiu arkhitekturu slishkom prosto, - ona ponimaetsia kak nabor starinnyk form, bol'shei chast'iu iz uvrazhei, bez vsiakoi rukovodiashchei religioznoi idei. I esli by eti khotia formy ostavalis' tochnymi v peredache, $t$. e. pravil'no by vykopirovyvalis'; net, ikh eshche staraiutsia ispravit', pridat' im t. naz. proportsii na ital'iano-frantsuzskii lad, chto $v$ kontse razrushaet dazhe tipichnost' starinnykh form $i$ daet nam ne tserkvi, raspolagaiushchie svoimi formami $i$ vnutrennim ubranstvom $k$ molitve, a prosto kakie-to, ne to tantsoval'nye, ne to kontsertnye, kriklivo $i$ grubo razmalevannye $i$ vyzolochennye zaly. Podobnye proizvedeniia raduiut $i$ dukhoventsvo $i$ prikhozhan svoim lozhnym velichiem $i$ bleskom $i$, vmesto razvitiia vkusa u prostoliudinov, privivaiut im liubov' ko vsemu blestiashchemu, no otniud' ne khudozhestvennomu.]

Like other contemporary critics, Shchusev saw Konstantin Ton as the initiator of the uninterrupted decline of taste in Russian church architecture.

In his desire to achieve a new creative interpretation of medieval forms, beyond thoughtless imitation, Shchusev followed the path of the Abramtsevo artists; and it is telling that his article should comment approvingly on the involvement of artists in the rediscovery of the beauty and sincerity of medieval art and architecture. This, he says, is an approach that should be emulated by architects:

We are convinced that architects too must grasp and sense the sincerity of ancient times, and creatively imitate it not in the copying out and correcting - i.e. distorting - of old forms, but in the creation of new forms in which there would be expressed, just as sincerely and beautifully as of old, the idea of a place of communion between the people and $\operatorname{God}^{22}$.

[My ubezhdeny, chto $i$ arkhitektoram neobkhodimo ulovit' $i$ pochuvstvovat' iskrennost' stariny i podrazhat' ei v tvorchestve 
ne vykopirovkoi starykh form i podpravleniem, t.e. porchei ikh, a sozdaniem novykh form, v kotorykh by vyrazhalas' tak iskrenne i tak krasivo, kak v starinu, ideia mesta obshcheniia liudei s Bogom.]

For Shchusev the primary goal is to create a place of worship whose interior and exterior would exemplify that "endearing, naive, and at the same time diverse sense of artistry of the Orthodox Church."

Shchusev's own contributions to the revival of church architecture were first presented to the public in the same year as his article, when he displayed his design for a church-monument at the Kulikovo Pole (Snipe Field) battleground during the 1905 Art and Architectural Exhibit in Petersburg. A revision of the project in 1908 revealed still further his attempt to recapture the "naive" quality of medieval church architecture, while emphasizing the plasticity of material and contour in the manner of the modern architectural aesthetic (Fig. 8) ${ }^{23}$. The project was not realized until 1913, but in the meantime Shchusev had embarked on the construction of a number of other churches, including the Trinity Cathedral at the Pochaev Monastery (Lavra) in 1905-12.

The Trinity Cathedral was the largest of Shchusev's churches, and the most faithful in its adherence to medieval prototypes - in this case, the early twelfth-century cathedrals at Novgorod's Iurev and Antoniev Monasteries ${ }^{24}$. Although the Pochaev Lavra, near Kremenets in the Ukraine, had become a major outpost of Russian Orthodoxy, the dominant architectural style was that of the Central European baroque, represented by the basilical design of the main Cathedral of

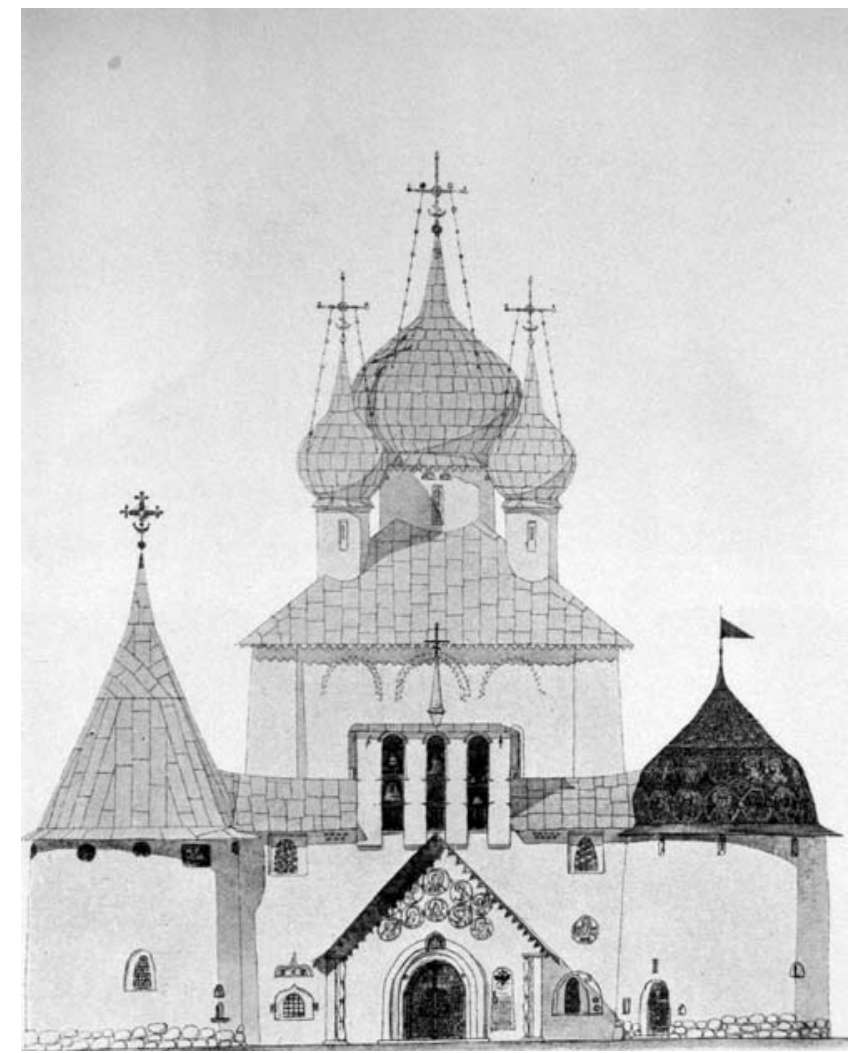

Fig. 8. Project sketch for church-monument at Kulikovo Field. 1908. Architect: Aleksei Shchusev. Ezhegodnik Obshchestva arkhitektorov-khudozhnikov, 1911 
the Dormition (1772-83). This is understandable in view of the monastery's location in an area, within $100 \mathrm{~km}$ of L'viv, that was not annexed by Russia until the third partition of Poland. There is no evidence that Shchusev personally was motivated by nationalist sentiment, yet the commission at Pochaev provided an opportunity to implement his reinterpretation of the Orthodox architecture of early medieval Rus', in a setting of opposition to the Catholic baroque of the Dormition Cathedral.

To this end the Trinity Cathedral incorporated, and in subtle ways exaggerated, certain prominent features of the Novgorod prototypes, such as an attached tower leading to the choir gallery and a large central dome with a helmet- shaped cupola (Figs. 9, 10). The whitewashed brick walls of the building provided a backdrop for the mosaic panels and wall paintings, designed by Shchusev and Nikolai Roerich, over the portals on the south, west, and north facades. The exterior walls also displayed ornamental brick motifs that more properly belong to fourteenth-century Novgorod architecture; but Shchusev was not concerned with a slavish imitation of his historical sources.

On the interior, wall paintings in the traditional manner by V. S. Shcherbakov decorated the galleries, although most of the central space was left unpainted. (Figs. 11, 12) A large iconostasis extended across the eastern bay of the church. While the Trinity Cathedral has been acknowledged as one of Shchusev's masterpieces, some have criticized it as excessively intellectual and deliberate in its attempt to recapture the aesthetic simplicity of Russia's early medieval churches $^{25}$. At the time of its completion, however, it was accorded the rare distinction of a special illustrated supplement composed of thirteen splendidly reproduced photographs in the 1912-13 Annual of the Moscow Architectural
Society $^{26}$. For Shchusev's contemporaries, his work at Pochaev represented a demonstration of the possibilities inherent in a revival of medieval religious architecture.

In addition to the Trinity Cathedral at Pochaev Shchusev adapted early medieval Orthodox architecture for other churches in the Ukraine, such as the Church of St. Panteleimon (1911) in Sumy. His most idiosyncratic use the medieval tradition occurred in Kharkov province on the estate of V. A. Kharitonenko, a wealthy merchant whose enlightened patronage and private setting encouraged a free experimentation similar to that at Abramtsevo. Completed in 1912, the Church of the Savior at Nataliivka was marked by a bulbous cupola of exaggerated proportions in comparison with the small drum and body of the church. (Figs. 13, 14) The walls were of ashlar limestone (rather than the more common brick), with ornamental carving on the west facade and on the drum. The most distinctive feature of this free combination of elements from medieval Novgorod and Suzdalia is the large attached belltower, whose sloping pylons framed openings extending over half the length of the tower ${ }^{27}$.

Of greater historical significance was Shchusev's design for the reconstruction, between 1907-09, of the Church of St. Vasilii in Ovruch a project that would elevate the architect in 1910 to the rank of Academician of Architecture at the Academy of Arts. Originally built around 1190 as the palace church of Riurik Rostislavich, the building was frequently damaged by the depredations of Mongols and Lithuanians, yet remained standing until 1846, when the vaulting of the roof collapsed. Shchusev had therefore to work with fragments of the structure, of which only the eastern and northern walls remained from the original church. Furthermore, standards of historical accuracy in the reconstruction of ancient monuments were considerably more 


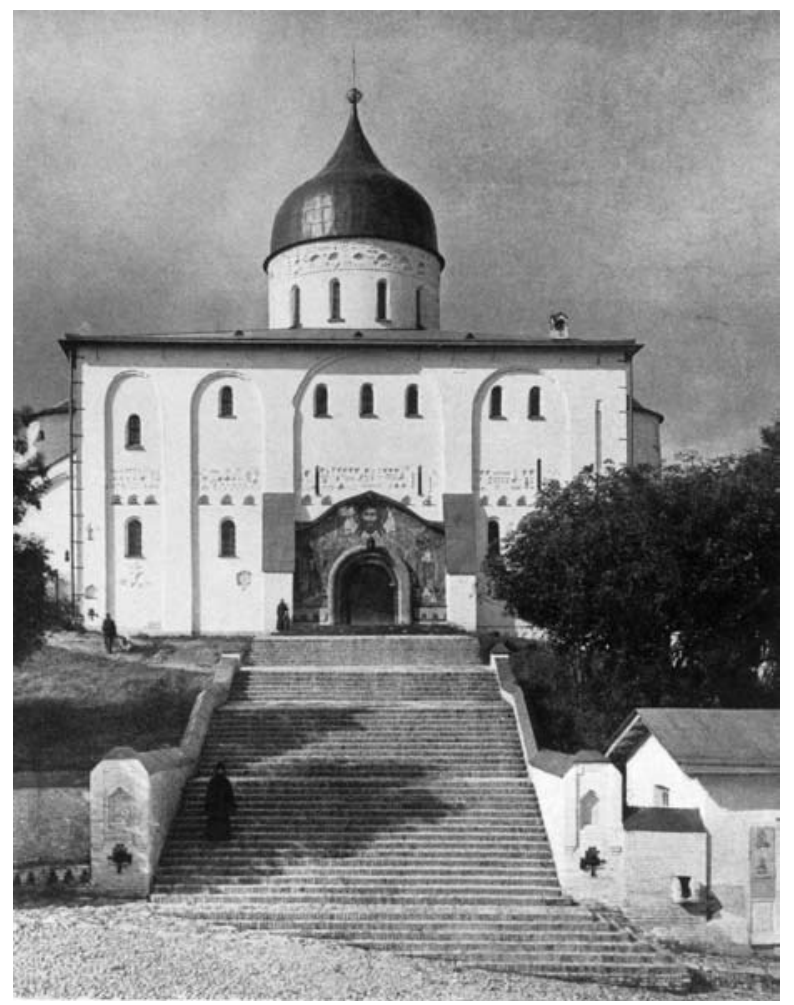

Fig. 9/ Pochaev Monastery. Trinity Cathedral. 1905-12. Architect: Aleksei Shchusev. South view. Ezhegodnik Moskovskogo arkhitekturnogo obshchestva, 1912-13

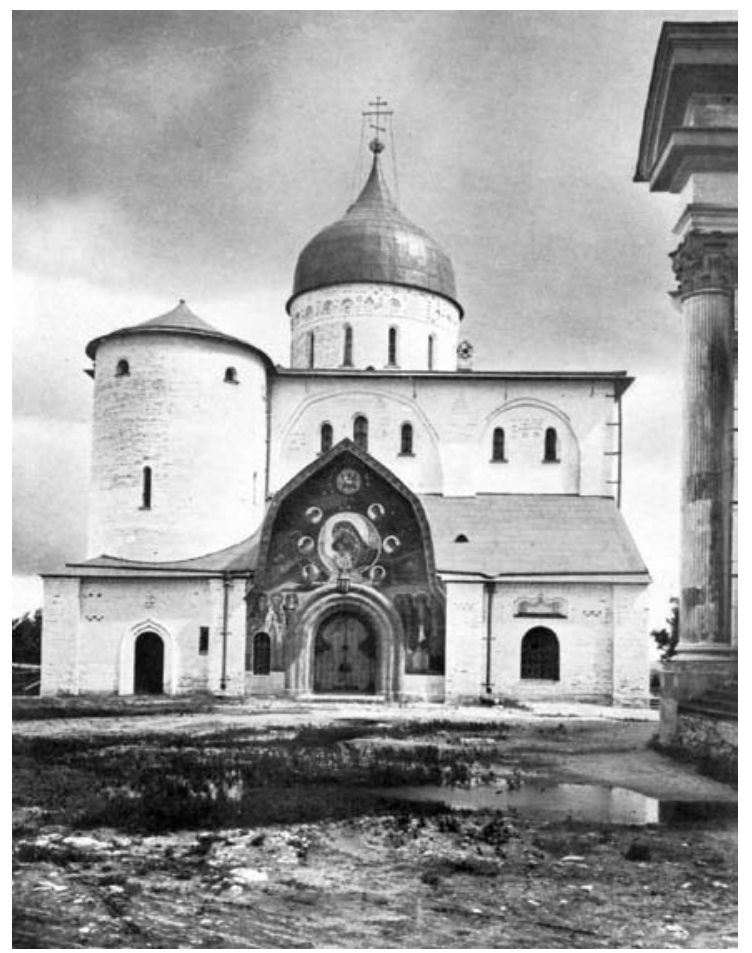

Fig. 10. Pochaev Monastery. Trinity Cathedral. West view. Ezhegodnik Moskovskogo arkhitekturnogo obshchestva, 1912-13 


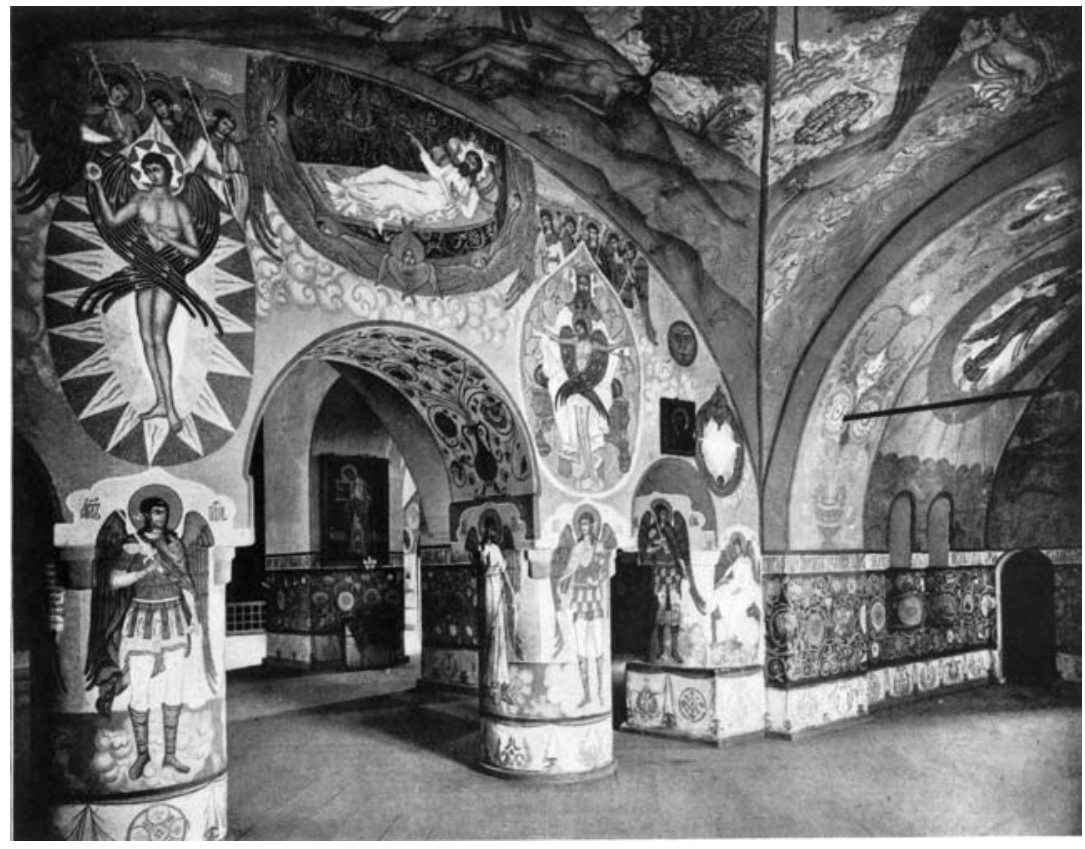

Fig. 11. Pochaev Monastery. Trinity Cathedral. Interior. Ezhegodnik Moskovskogo arkhitekturnogo obshchestva, 1912-13

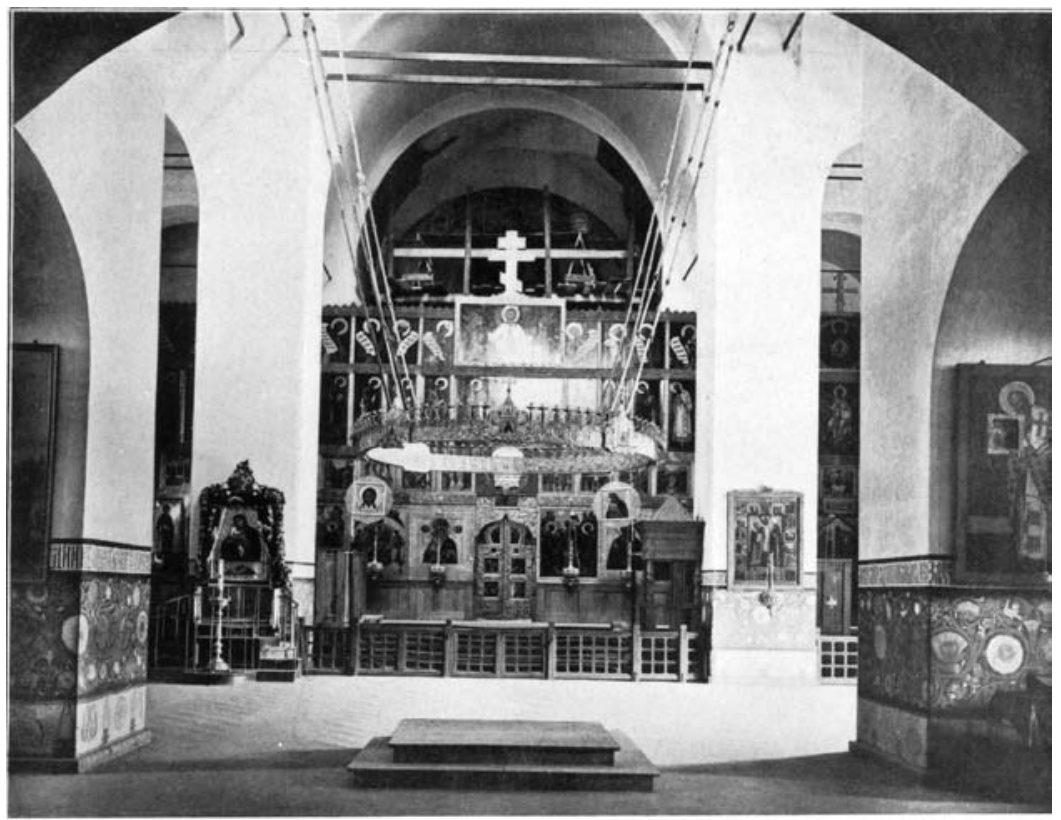

Fig. 12. Pochaev Monastery. Trinity Cathedral. View toward iconostasis. Ezhegodnik Moskovskogo arkhitekturnogo obshchestva, 1912-13 


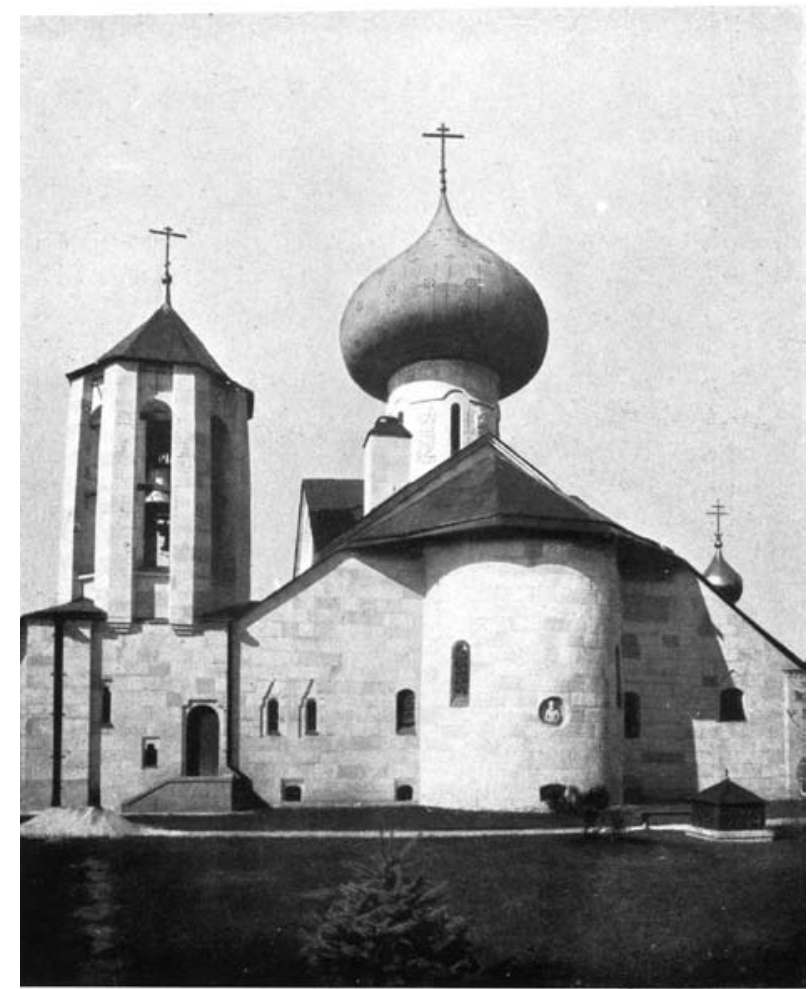

Fig. 13. Natalievka. Church of the Savior. 1912. Architect: Aleksei Shchusev. East view. Ezhegodnik obshchestva arkhitektorov-khudozhnikov, 1915

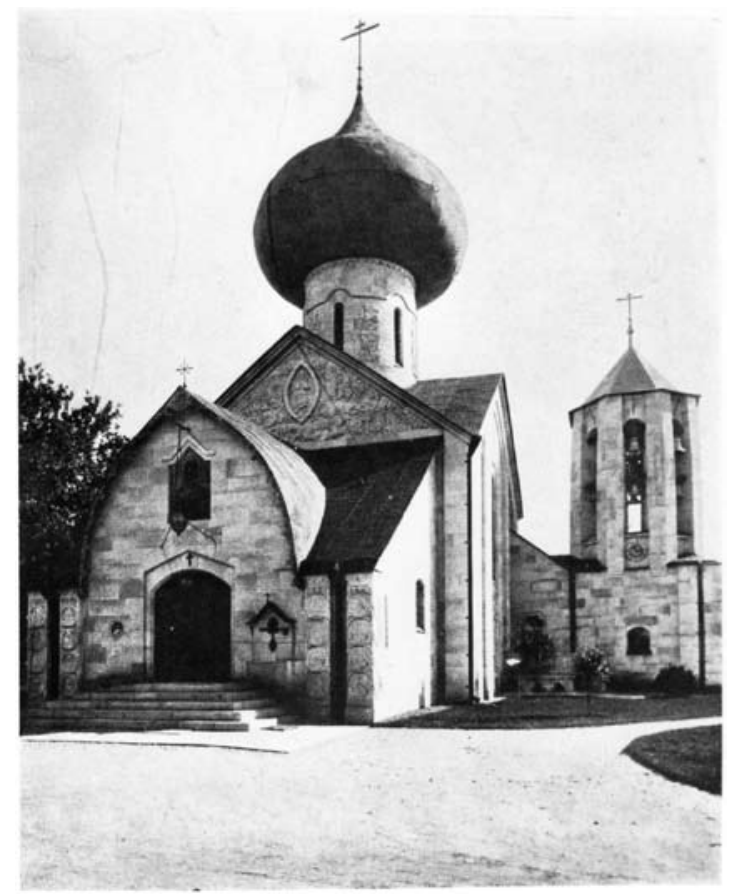

Fig. 14. Natalievka. Church of the Savior. 1912. Architect: Aleksei Shchusev. West view. Ezhegodnik Obshchestva arkhitektorov-khudozhnikov, 1915 
rigorous than those applied earlier in the nineteenth century.

In order to maintain a sense of authenticity in the reconstruction, Shchusev consulted with P. P. Pokryshkin, a specialist in medieval Russian architecture, who had recently (1903-04) guided the capital restoration of the late twelfth-century Church of the Transfiguration of the Savior on the Nereditsa, near Novgorod ${ }^{28}$. Pokryshkin's investigation of extant fragments of the church at Ovruch provided the data upon which the architect based his design; and without doubting the historical integrity of his effort, it must be noted that the reconstructed building shows an affinity with the aesthetic and tectonic principles of the new style in church architecture - particularly in the attached rounded towers on either side of the west front, and the curved roof line. (Fig. 15) The interior, which retained small fragments of the original wall, was painted in imitation of the well-preserved frescoes of the Nereditsa church, whose dates are contemporary with the Church of St. Vasilii ${ }^{29}$. Shchusev's project at Ovruch also included the design of adjoining conventual buildings (completed in 1912), with white-washed walls and steeply-pitched roofs derived from the architecture of medieval Pskov. (Fig. 16)

Although the great majority of Shchusev's churches were built in rural or monastic settings, he undertook one major project in his adopted city of Moscow before the Revolution: the Church of the Intercession (1908-12) at the Martha-Mary cloister, a religious and charitable foundation supported by Grand Duchess Elizaveta Fedorovna. Like the Trinity Cathedral at Pochaev - as well as many of his other churches the Church of the Intercession shows a stylistic affinity with twelfth-century monastery churches

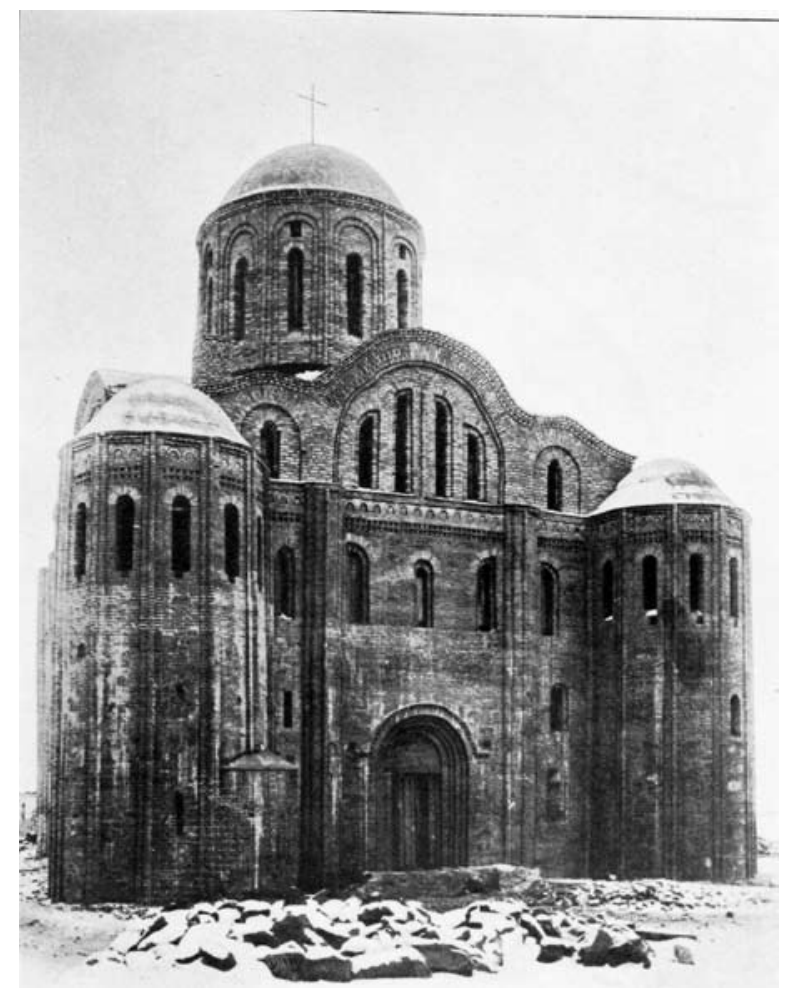

Fig. 15. Ovruch. Church of St. Basil. Originally built ca. 1190; restored in 1907-09 by Aleksei Shchusev. West view. Ezhegodnik Moskovskogo arkhitekturnogo obshchestva, 1912-13 


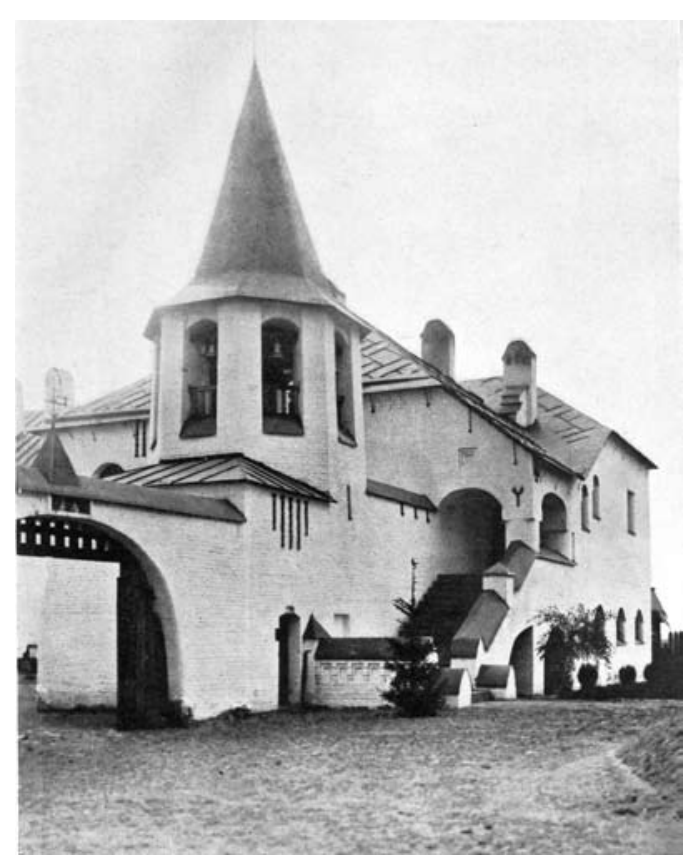

Fig. 16. Ovruch. Convent adjacent to Church of St. Basil. Architect: Aleksei Shchusev. Ezhegodnik Moskovskogo arkhitekturnogo obshchestva, 1912-13

in Novgorod, but interpreted in a rather general, abstract manner. The unstuccoed walls of uniform brick, the pointed gables, and exaggerated proportions of both apse and refectory have no direct antecedents in Novgorod churches, nor does the ornamental limestone carving placed in a deliberately haphazard fashion on the walls of the north porch.

The Church of the Intercession is in fact a combination of elements from several medieval "schools" (exemplified by the carved limestone portals in the manner of late twelfth-century Vladimir), and as such is directly related to its predecessor in the free style at Abramtsevo, which also combined the Suzdalian limestone carving with the plasticity of Novgorod brick churches. Only the simplified, or "naive," outlines of the structure suggest the debt to the tectonic clarity associated with Novgorod and Pskov. (Fig. 17) In striving to recapture the medieval spirit in decoration as well as architecture, the interior of the church was painted by Mikhail Nesterov, who imitated some of the stylized effects of medieval frescoes, even though he is known primarily for his detailed, realistic technique in oil paintings on mystical and religious themes ${ }^{30}$.

One critic has noted that while Shchusev understood the desirability of placing such a stylization in a natural setting appropriate to the forested northern landscape, the location of the Church of the Intercesssion in a thickly populated section of Moscow (on the Ordynka in Zamoskvoreche) encourages a perception of the building as a "theatrical trinket," isolated from its surroundings only partially by a high wall and small park ${ }^{31}$. This criticism, accurate as to Shchusev's original intention to situate the church on a forested plot, is excessively literal in view of the urban environment of Moscow, where a seventeenth-century parish church is likely to be situated next to an apartment block. Furthermore, Shchusev's careful attention to the design of the cloister wall and gates, whose wrought-iron grate 


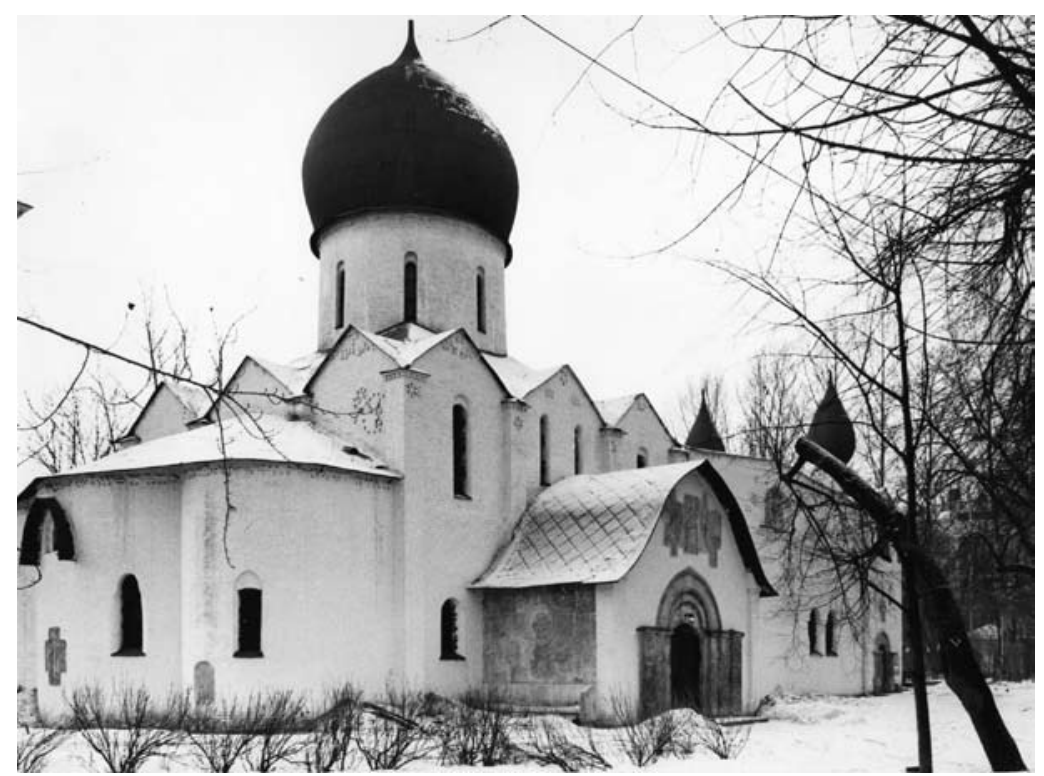

Fig. 17. Moscow. Church of the Intercession, Mary-Martha Cloister. 1908-12. Architect: Aleksei Shchusev. Photo: William Brumfield

framed a view of the church, suggests an image of walled monastery compounds that were common in Russian towns during the medieval period.

After 1910 architects based in Moscow continued to pursue concepts in church design that united traditional or medieval elements in the free approach of the style moderne, although the emphasis on plasticity yielded to a greater clarity of outline and a lessening of interest in ornamental details. Shekhtel, who had contributed little in this area since his efforts at turn of the century, returned to church design toward the end of his active career. While his earlier churches displayed an aesthetically conservative approach uncharacteristic of his secular buildings, his work from the years 1910-14 reinterpreted traditional forms, without decoration, as a new, "rationalized" tectonic system. For Shekhtel the major source of inspiration was the sixteenth-century tower church, with its elongated, pyramidal "tent" roof over a narrow central structure; yet in his 1910 design for an Old Believer church at Balakovo (situated on the Volga River between Samara and
Saratov), he made the daring technical move of placing the "tent" over a larger, cuboid structure of ashlar. (Fig. 18) In the design of the tent tower, unobstructed by exterior ornament, Shekhtel's church at Balakovo exemplified the uses of modern construction techniques in recreating a distinctive feature of the Russian church before the Schism, or raskol, of the mid-seventeenth century.

Shekhtel's final church, dedicated to St. Nicholas the Miracle Worker, was built between 1914-16 in the Moscow suburb of PetrovskoRazumovskoe, and represented his most sensitive recreation of a traditional design for Russian wooden churches - an octagon over a square, with a tent tower. (Fig. 19) So rigorous is its adherence to this form, that one might assume the church to be a replica; yet the shape of the building, with its plank siding, places a modern emphasis on the fluidity of contour, from the central tower to the large extensions (each with its own roof) attached to the main cube of the structure on the north, south, and west. Shekhtel's adaptation 


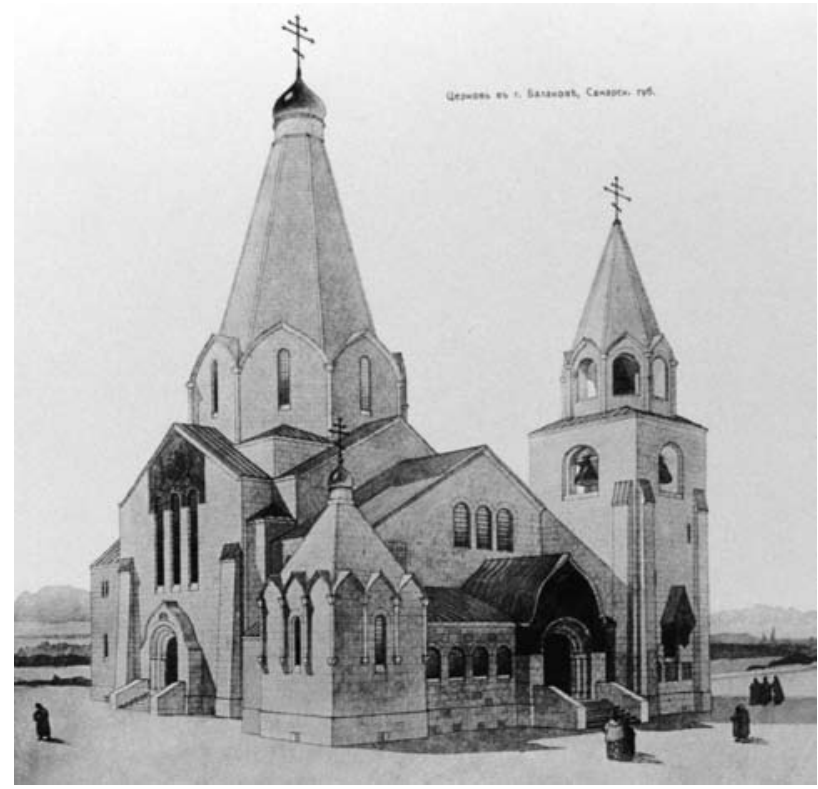

Fig. 18. Project sketch for Old Believer church at Balakovo. 1910. Architect: Fedor Shekhtel. Zodchii, 1911

of the centralized form of the tower church conveyed a sense of spatial unity on both interior and exterior, and was complemented by his design of the iconostasis and furnishings. Early photographs of the building (not extant) show a remarkable interior, contrasting the carving of the iconostasis with a pattern of unpainted knotty pine for the walls ${ }^{32}$. (Fig. 20) As did his mentor Viktor Vasnetsov at Abramtsevo, Shekhtel used church design as an ideal means of expressing the integration of structure and the decorative arts, with the added emphasis on the aesthetic properties of wood.

The traditional tent form of the tower church assumed a more exhuberant form in the Church of the Resurrection in Sokolniki (1909-1913), by P. A. Tolstykh. Although the style moderne - at least in its highly decorative, flamboyant mannerhad disappeared as a viable movement in Russian secular architecture by 1909, Tolstykh's design nonetheless shows the influence of the moderne in its emphasis on the curved line of the structure, both in the molded contours of the bays and the apse and in the color of the church. (Fig. 21) The use of stuccoed brick for the exterior walls permitted a bichromatic application of paint, with the main structural components of the building outlined in white on a green background, above which arose a brilliant array of cupolas surrounding the central tower.

This functioning Orthodox church, which is still maintained in excellent condition, represents a significant social aspect in the revival of church architecture: the funds for its construction were raised by a neighborhood committee headed by the priest I. I. Kedrov ${ }^{33}$. As a display of local initiative, the project provided an alternative to the officially sponsored (and designed) Orthodox church on the one hand, and the private chapel or estate church on the other. While the Old Believer communities had already established the principle of local initiative in construction of churches, the Church of the Resurrection represents the new style in Orthodox church architecture as an emblem of the revived expression of religious values in an urban community.

The juxtaposition of religious and secular architecture in the work of numerous Moscow 


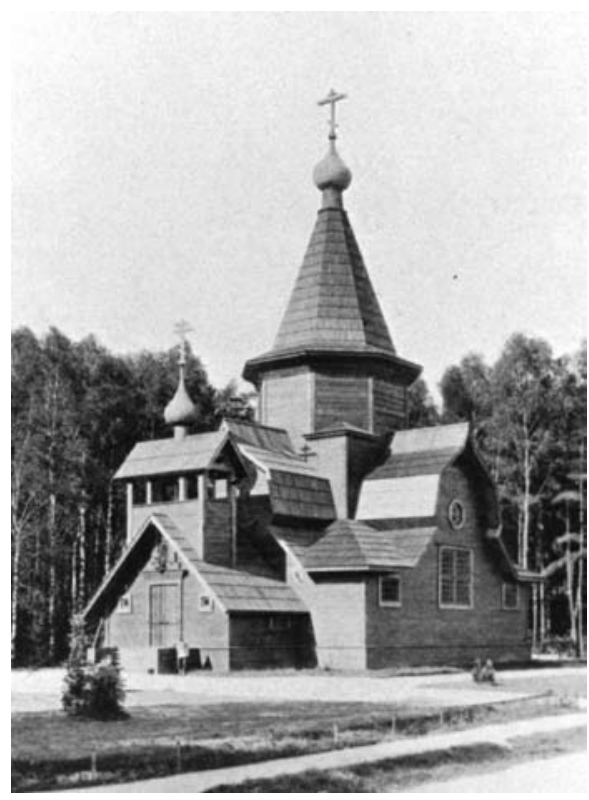

a

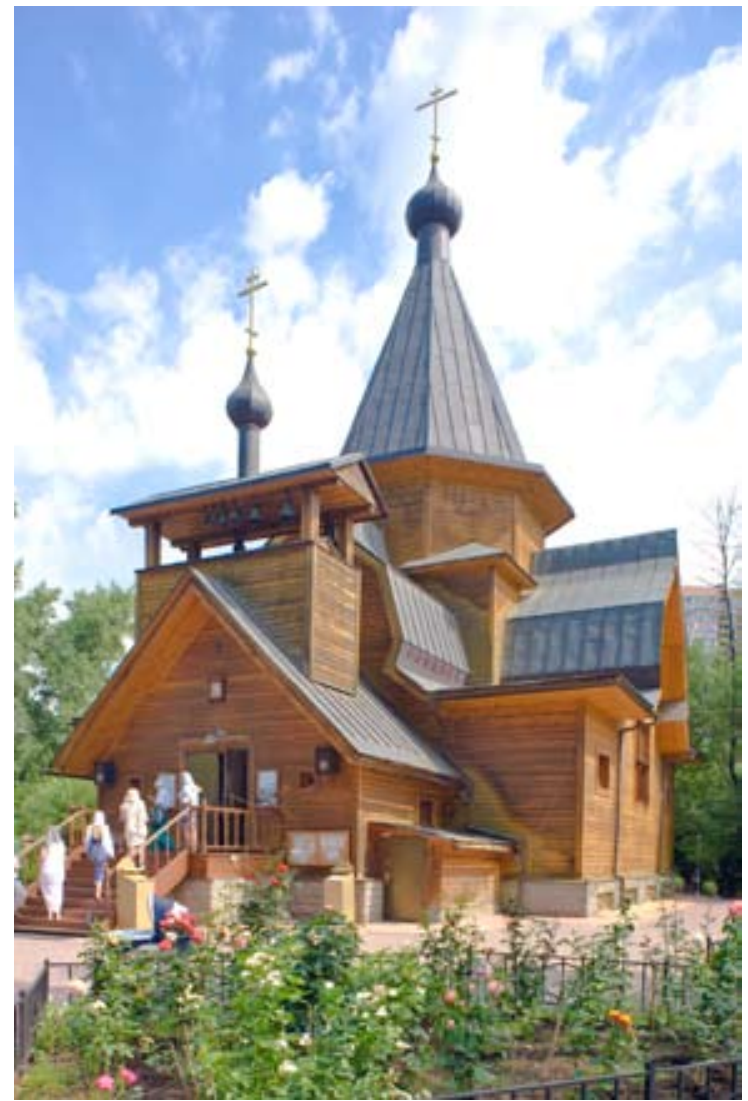

b

Fig. 19. Moscow. Church of St. Nicholas "u Solomennoi storozhki”, at Petrovskoe-Razumovskoe (destroyed). Architect: Fedor Shekhtel. Southwest view. Ezhegodnik Moskovskogo arkhitekturnogo obshchestva, 1914-16 (a); Moscow. Church of St. Nicholas "u Solomennoi storozhki” (rebuilt 1996-97). Southwest view. Photo: William Brumfield (b) 


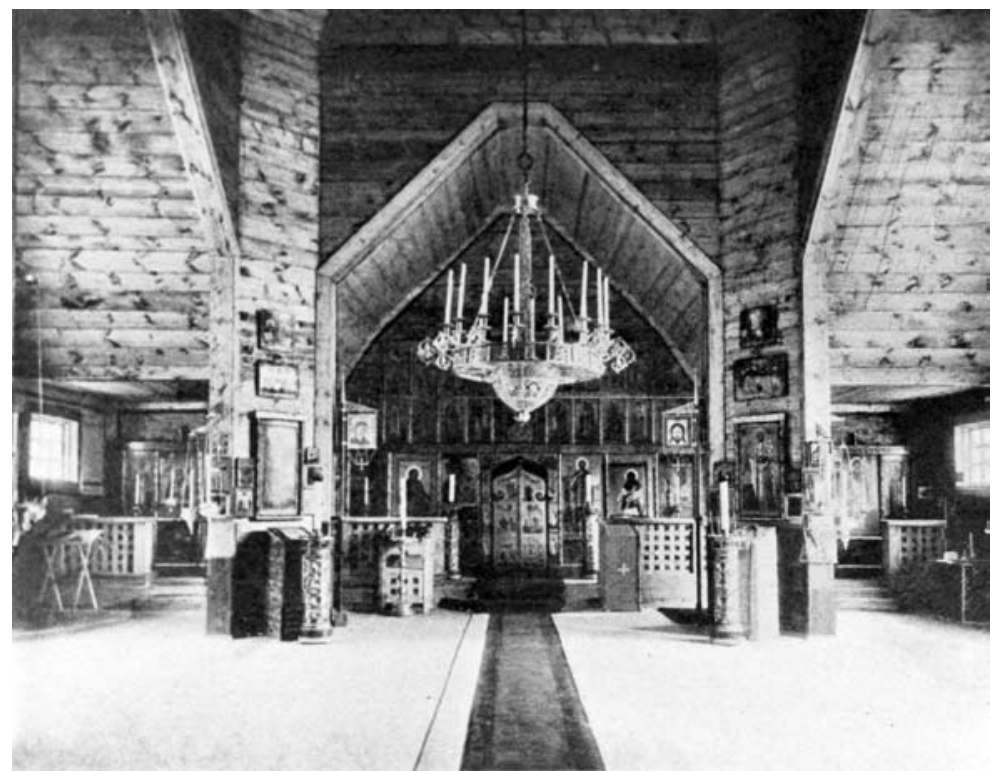

Fig. 20. Moscow. Church of St. Nicholas "u Solomennoi storozhki”, at Petrovskoe-Razumovskoe (destroyed). Architect: Fedor Shekhtel. Interior. Ezhegodnik Moskovskogo arkhitekturnogo obshchestva, 1914-16

architects suggests a persistent interest in medieval architecture as a source of inspiration for new approaches to structure. Ivan Kuznetsov, who designed office buildings in an austere functional style in central Moscow, created a striking effect for a new church at the village of Tezino (ca. 1911, Kostroma Province). Although the main structure is closely based on large sixteenth-century monastery churches, the dominant - indeed, overwhelming - feature of the design is the bell tower attached to the west

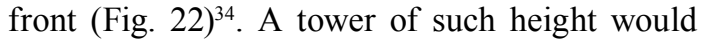
not have been unusual within a major monastic compound, but its appearance as part of an isolated church of otherwise traditional design is indicative of a contradictory impulse in late imperial church architecture: slavish imitation of medieval prototypes combined with a hypertrophied adaptation of selective elements either decorative or structural.

Other Moscow architects known primarily for their secular structures also produced church designsduringthedecadebeforetherevolution. The brothers Leonid, Viktor, and Aleksandr Vesnin, three of the most prominent representatives of Soviet constructivism, built at least four churches in Nizhnii Novgorod province and one in Moscow province ${ }^{35}$. Indeed, during their student years at the Institute of Civil Engineering, Viktor and Aleksandr Vesnin designed a "tent" tower church for Balakovo (1908; Fig. 23) that is considerably more flamboyant than Shekhtel's winning entry in the same competition. Aleksandr Vesnin also participated as one of the on-site architects for Shchusev's rebuilding of the Church of St. Vasilii at Ovruch.

In contrast to Moscow, church design in Petersburg adhered more closely to prevailing "official" styles - as might be expected of the capital and seat of the Holy Synod. The most notable example of the quasi-Russian style (to use Aplaksin's term) is the Church of the Resurrection of the Savior on the Blood, built on the Catherine Canal between 1882-1907 to a design by Alfred Parland (Fig. 24). The form and much of the decoration derive from sixteenth 


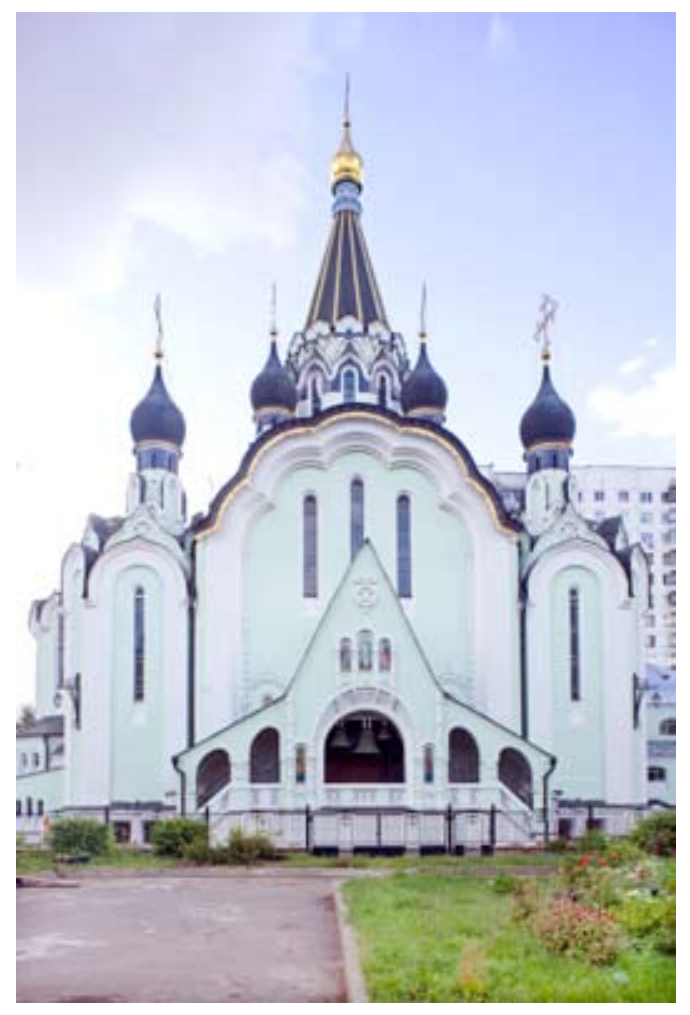

a

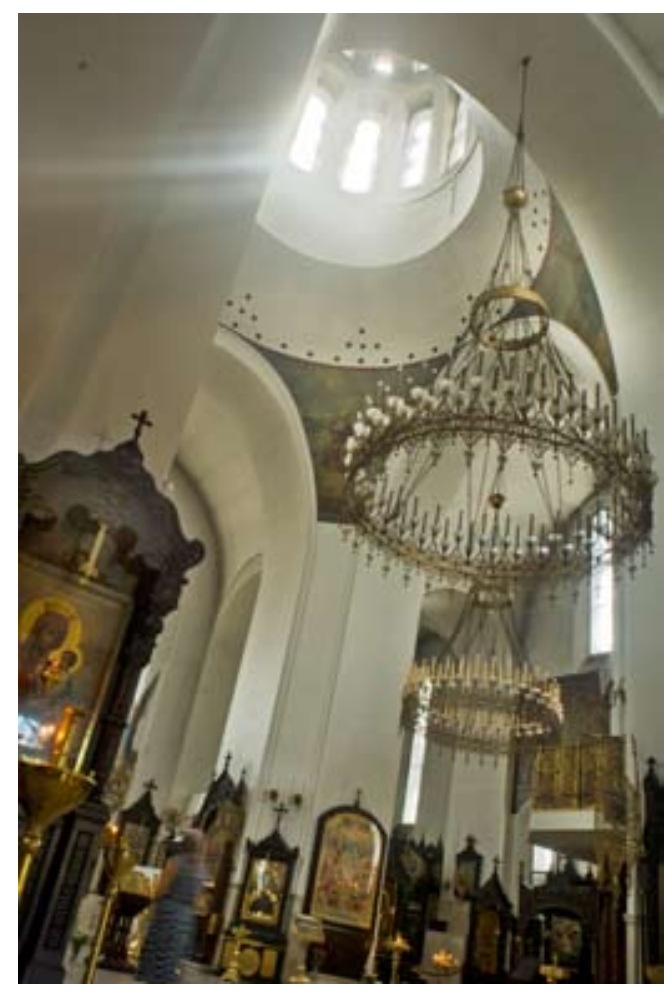

c

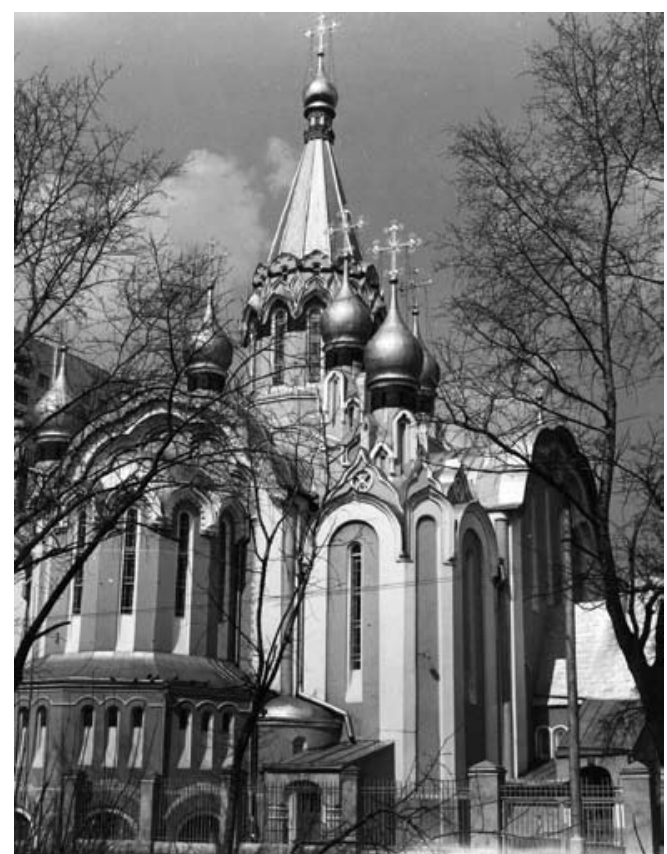

b

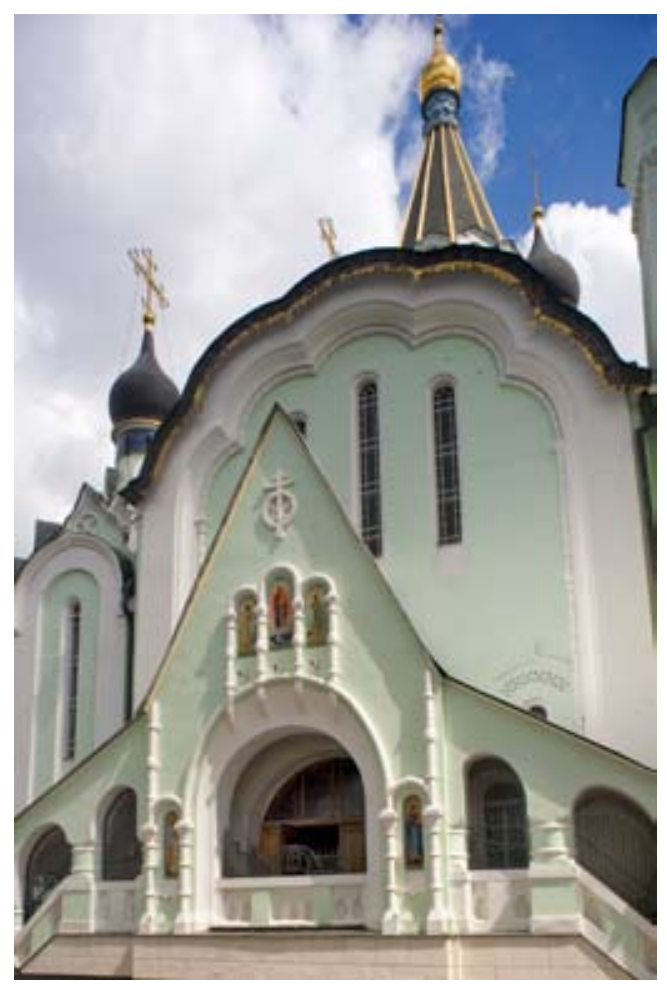

d

Fig. 21. 21A. Moscow. Church of the Resurrection in Sokolniki. 1909-13. Architect: P. A. Tolstykh. North view (a); East view (b); Interior (c); South view(d). Photo: William Brumfield 


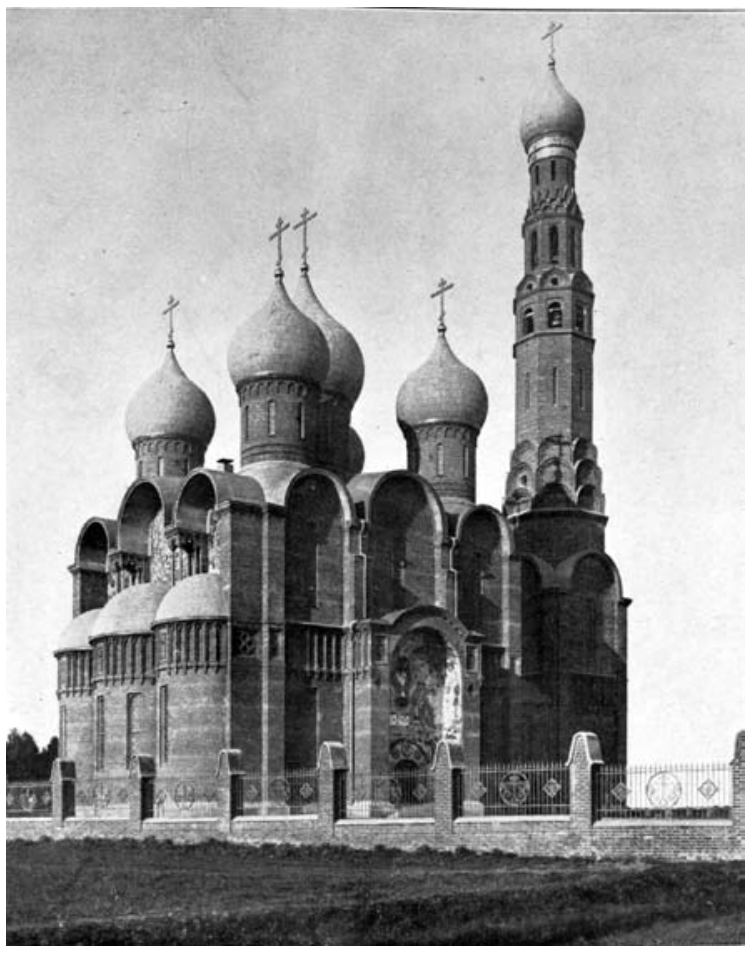

Fig. 22. Vichuga. Church of the Resurrection in Tezino. 1911. Architect: Ivan S. Kuznetsov. Northeast view. Ezhegodnik Obshchestva arkhitektorov-khudozhnikov, 1912

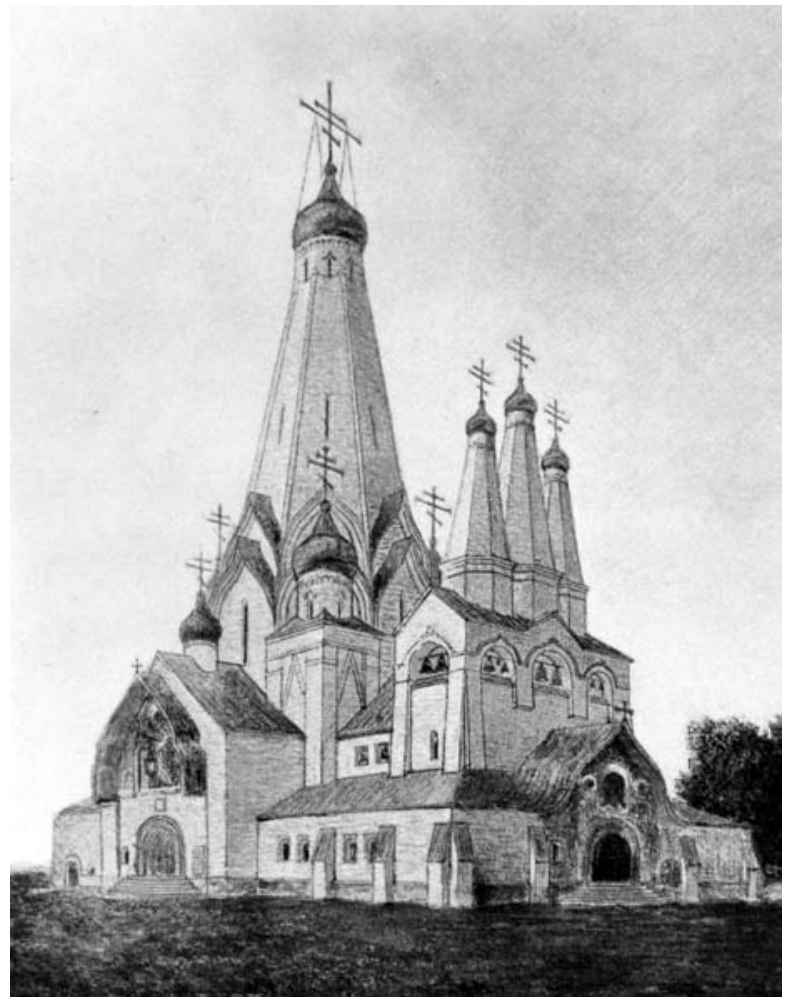

Fig. 23. Project sketch for Old Believer church at Balakovo. Architects: Alexander Vesnin, Viktor Vesnin. Zodchii, 1911. Ezhegodnik Moskovskogo arkhitekturnogo obshchestva, 1909 


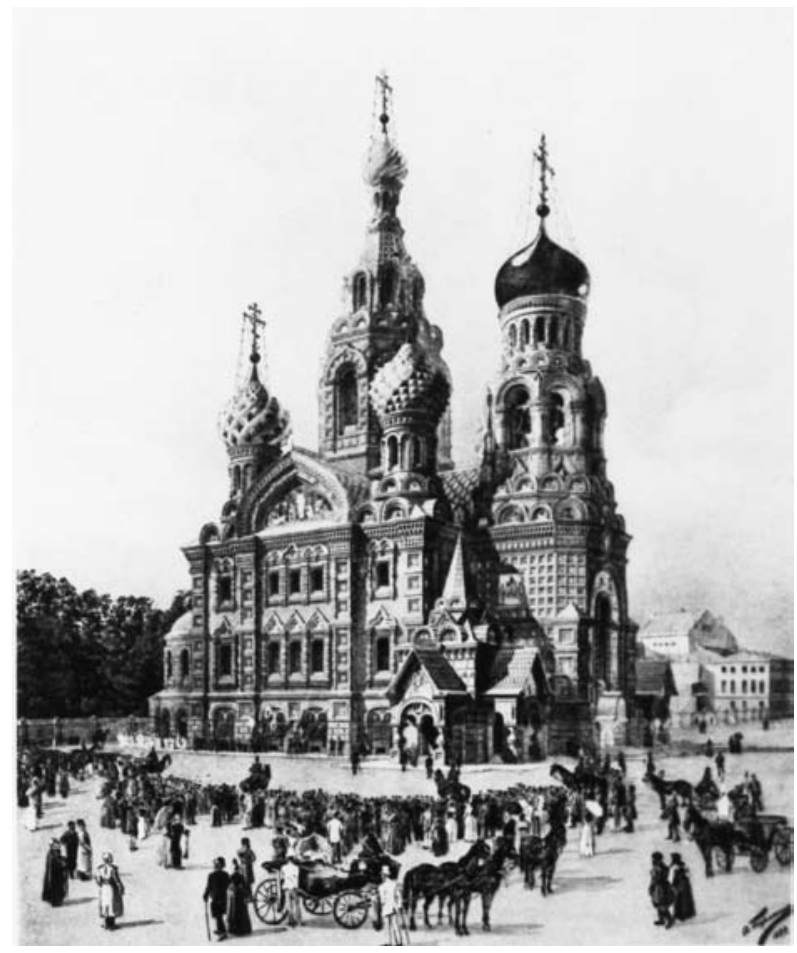

Fig. 24. St. Petersburg. Project sketch for Church of the Resurrection of the Savior on the Blood. Architect: Alfred Parland. Zodchii, 1907

and seventeenth-century Muscovite architecture, without capturing the structural logic of such putative antecedents as the Cathedral of the Intercession on Red Square (St. Basil's). Although an impressive technical achievement, in both its structural engineering and mosaic work, the church represented the union of official ideology and national style that was rejected by a large segment of architectural opinion at the beginning of the century ${ }^{36}$.

The ability of this union to assume a wide variety of forms is evident in such examples as Marian Peretiatkovich's Church of Christ the Savior (1909-11; not extant), a reproduction of the late twelfth-century Cathedral of St. Dmitrii in Vladimir. As a memorial to the sailors who died in the Russo-Japanese War, it serves less effectively than Karl Isenberg's 1911 monument to those who perished with the sinking of the "Steregushchii" during the same war. An equally cold manner characterizes the two churches of Stepan Krichinskii, including a large ensemble commemorating the tercentenary of the Romanov dynasty and built to a design derived primarily from the late seventeenth-century kremlin at Rostov (Fig. 25) ${ }^{37}$. All of the above buildings were surfaced in ashlar limestone - an unusual and not particularly successful choice in the Petersburg setting, but an indication of the considerable financial support expended on projects with official blessing.

The most prolific builder of churches in Petersburg at the beginning of the century was Vasilii Kosiakov, who adopted the RussoByzantine style for most of his eight churches still standing in various states of disrepair throughout the city and its environs (including two on Vasilevskii Island). His grandest use of the Byzantine style appeared in the cathedral at the naval base of Kronshtadt (1902-13), a 


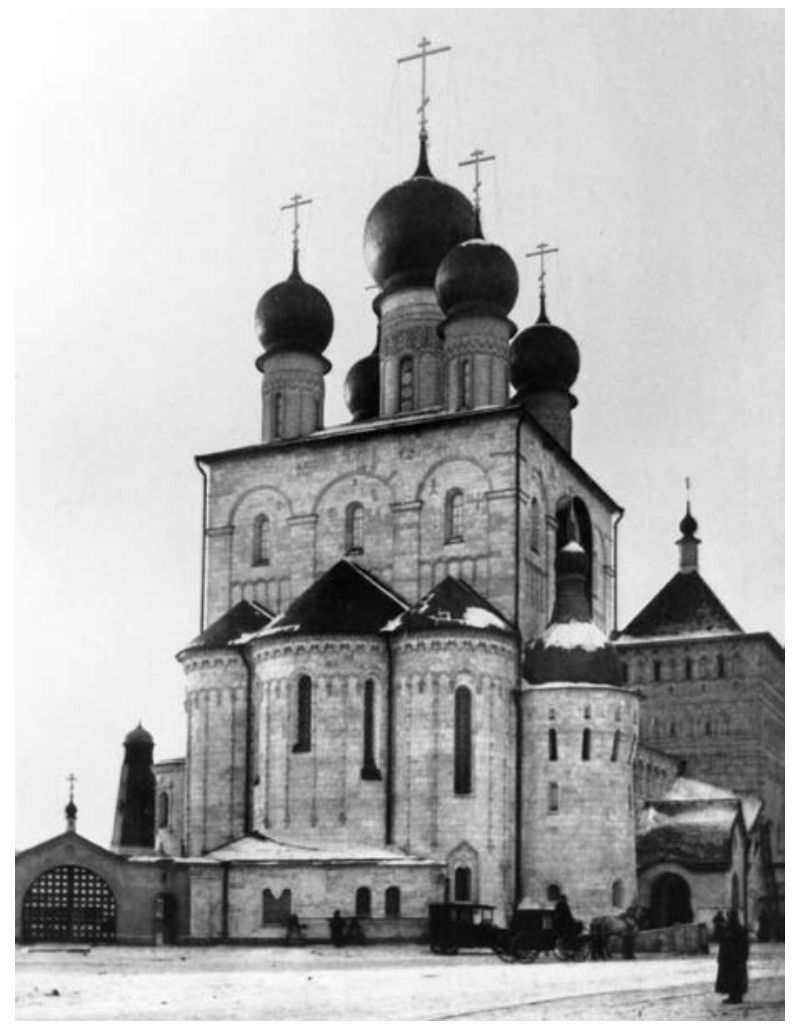

Fig. 25. St. Petersburg. Church-monument to the Tercentenary of the Romanov Dynasty. 1911-13. Architect: Stepan Krichinskii. Zodchii, 1914

building whose proportions and lavish interior decoration exceed that of any other late imperial church in Petersburg and point, once again, to the ideological and political overtones of official church architecture during this period ${ }^{38}$.

The major exception to such architectural pomposity occurred, not surprisingly, in Dmitrii Kryzhanovskii's 1906 design of a church for the Petersburg community of Pomortsy. Although there were fewer Old Believer churches in Petersburg than Moscow, the Pomorskii Covenant in the capital was sufficiently well endowed to commission a church from one of the city's most prominent architects, and in a style that again combined medieval antecedents with the modern construction methods. There is little surface decoration on the exterior of the building, whose form imitates the molded structure of late fourteenth-century Novgorod churches, with their curved, trefoil roof line. (Fig. 26) The church, of brick walls surfaced with cement stucco, was set back from the street and surrounded by a low wall, thus creating an enclosed space, whose entrance gate was marked by a free-standing bell tower (zvonnitsa).

On the interior the cross-inscribed plan enclosed a cuboid structure that supported a complex system of ferroconcrete vaults and five cupolas, of which the main drum and cupola provided natural light for the central space. Although the placement of the cupolas and the general shape of the roof appear closely related to medieval Novgorod architecture, the cube represents a major deviation from the prototpye and reminds of the free combination of elements typical of the new style in church 


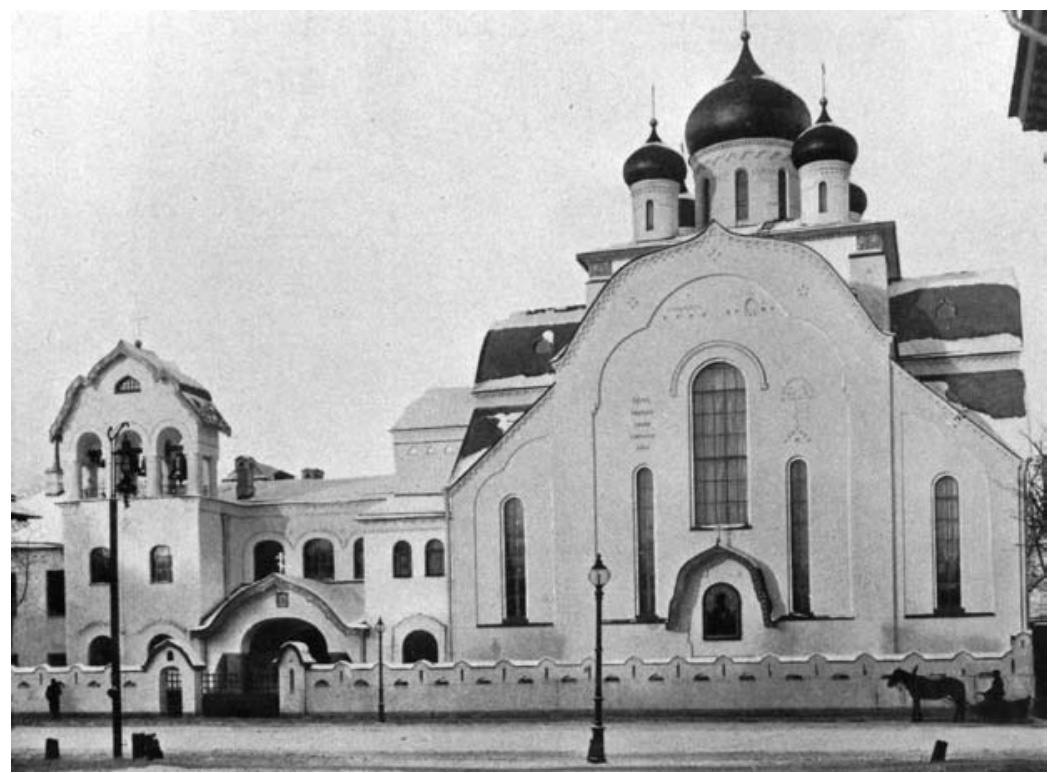

Fig. 26. St. Petersburg. Old Believer Church for the Pomorskii Covenant. 1906. Architect: Dmitrii Kryzhanovskii. Ezhegodnik obshchestva arkhitektorov-khudozhnikov, 1908

architecture. The author of an extensive report on the church in Zodchii noted with approval that the smooth, stuccoed interior walls were left unpainted (the usual practice in the new sectarian churches), thus allowing an unhindered perception of the contours of the vaulted structure ${ }^{39}$.

The visual dominant of the interior was the icon screen, which included both ancient and contemporary icons (the latter had to be painted in the old style by members of the Pomorskoe soglacie). Also of interest were furnishings such as the gonfalon (horugv') and large chandelier (panikadilo), both designed after medieval examples by Sergei Vashkov and crafted by the Olovianishnikov firm. It should be noted that Shchusev's churches were also distinguished by the high quality of such religious furnishings, particularly at Pochaev, whose great chandelier was suspended from the pendentives of the main dome. The emphasis on craftsmanship in church furnishings, introduced by Viktor Vasnetsov and Vasilii Polenov at Abramtsevo, is an integral part of the renascence of Russian church architecture. By combining ancient prototypes with the style moderne in the decorative arts, both Vashkov and the Olovianishnikovs assumed a leading role in the design and production of furnishings commensurate with the new architectural setting.

During the final decade before the revolution, the work of Vladimir Pokrovskii represented both the culmination and the decline of the revival in Russian church architecture. Although a resident of Petersburg, Pokrovskii received commissions for Orthodox churches throughout the European part of the Empire, including the Ukraine (in this respect his career parallels that of Shchusev). In addition he was the architect of a number of secular projects in Moscow, Nizhnii Novgorod, and Petersburg; yet his fame rested largely on a series of church designs distinguished by their large size and a neo-historicist approach to style ${ }^{40}$. Pokrovskii began by assimilating the approach of the new style to the medieval period in church architecture, with its emphasis on 
texture and the sculpted form, and then applied it on a hypertrophied scale.

The love for textural contrast (wood, stone, brick) and plasticity of form that characterized the style moderne is evident in his church designs from the beginning of the century, such as the church on the outskirts of Schlisselburg (at as powder factory to the northeast of Petersburg; completed by 1906), whose "tent" tower soars above a cruciform structure with a steeply curved gable line ${ }^{41}$. (Figs. 27, 28) Pokrovskii had rediscovered the tectonic effect of the vertical in church architecture, and all of his major church designs show it in some form.

For the Church of the Intercession at Parkhomovka (1903-06; near Kiev), he abandoned the Orthodox cross- inscribed plan for an elongated, basilical structure dominated by an enormous bell tower over the west front. (Figs. 29, 30) Above the recessed main portal, with romanesque arch, Nikolai Roerich designed a monumental mosaic representation of the Intercession of the Mother of God, which fills most of the central bay. In almost every respect Pokrovskii deviated from accepted practice in Orthodox architecture, and yet the three bays of the west front were arranged in the trefoil pattern of fourteenth-century Novgorod churches. The Church of the Intercession comprises the most unusual combination of elements from Western and Eastern Christianity in the Russian empire at the beginning of the century; and this free style appeared also in the ancillary structures of the church (particularly the main gate to the compound $)^{42}$.

Pokrovskii's imagination seems to have been endlessly productive in the matter of churches, and a detailed survey of his designs and completed churches would require a separate study. Yet there is one other monument by Pokrovskii that will serve as a fitting culmination to Russian church architecture in the new style. In fact the building is more monument than church, since it was intended to commemorate the victory over Napoleon - and Russian participation therein at the Battle of Nations in 1813. Constructed near Leipzig in 1912-13, the building derives in the most obvious way from the Church of the Ascension at Kolomenskoe (1530-32), which is in turn the clearest expression of verticality in old Russian architecture.

This choice of prototype had much to recommend it: the Church of the Ascension was itself a votive church, a monument to the succession of the Grand Princes of Muscovy. In addition its vertical design with tent tower was frequently paraphrased in churches of the new style, and could be considered a model of structural clarity in which all elements are subordinate to the dominant idea. Nonetheless, the monument at Leipzig is the most rigid of Pokrovskii's churches in its interpretation of the past ${ }^{43}$. (Fig. 31) Paradoxically, the architect attempted to rationalize a historical structure, and yet betrayed the free-style principles of the new architecture without capturing the essence of its historical prototype. In his simplification of the complex, yet perfectly functional system of vaults and support walls at Kolomenskoe, Pokrovskii eliminated a vital display of tectonic logic, and produced another ponderous monument to the exhausted myth of imperial Russian grandeur.

In the years immediately preceding the First World War, the large scale of officially-sponsored church architecture, exemplified by Pokrovskii's Sovereign Cathedral of the Fedorov Icon of the Mother of God at Tsarskoe Selo (1910-1912: Fig. 32), reflects a retreat into an imitation of the past that characterized so much in the attitudes of court society in the waning days of the empire. And within the pragmatic, secular environment of the Russian architectural profession, the aestheticization of medieval church styles spoke 


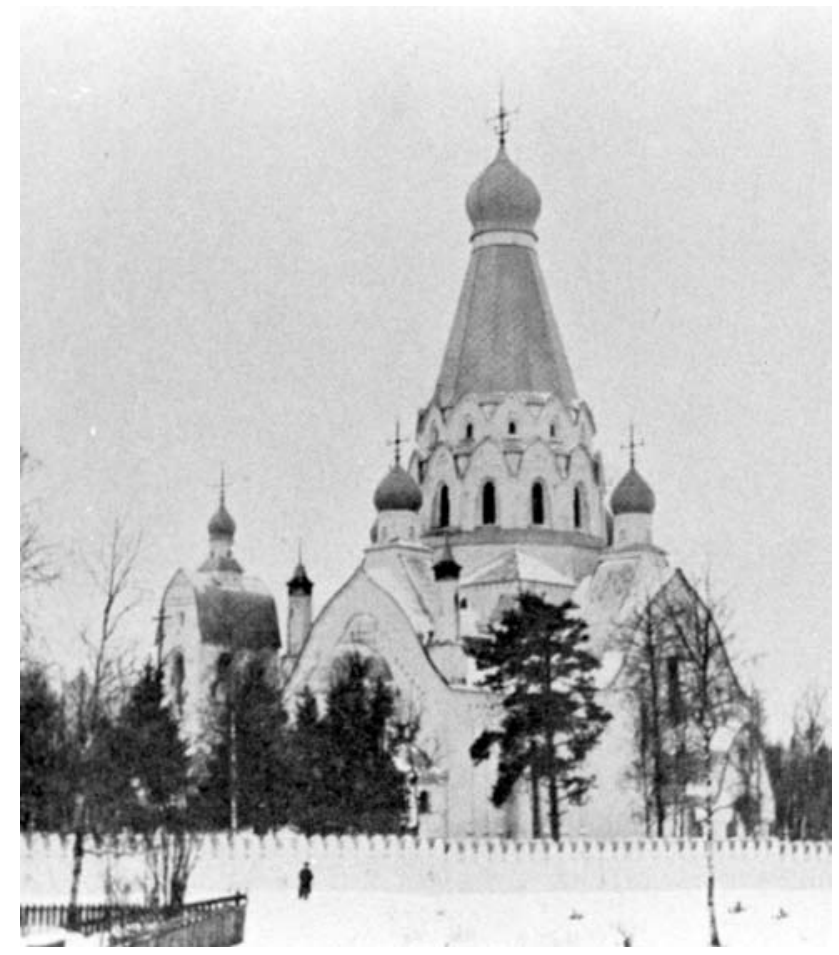

Fig. 27. Schlisselburg. Church at powder factory. 1906 (destroyed during World War II). Architect: Vladimir Pokrovskii. Ezhegodnik Obshchestva arkhitektorov-khudozhnikov, 1907

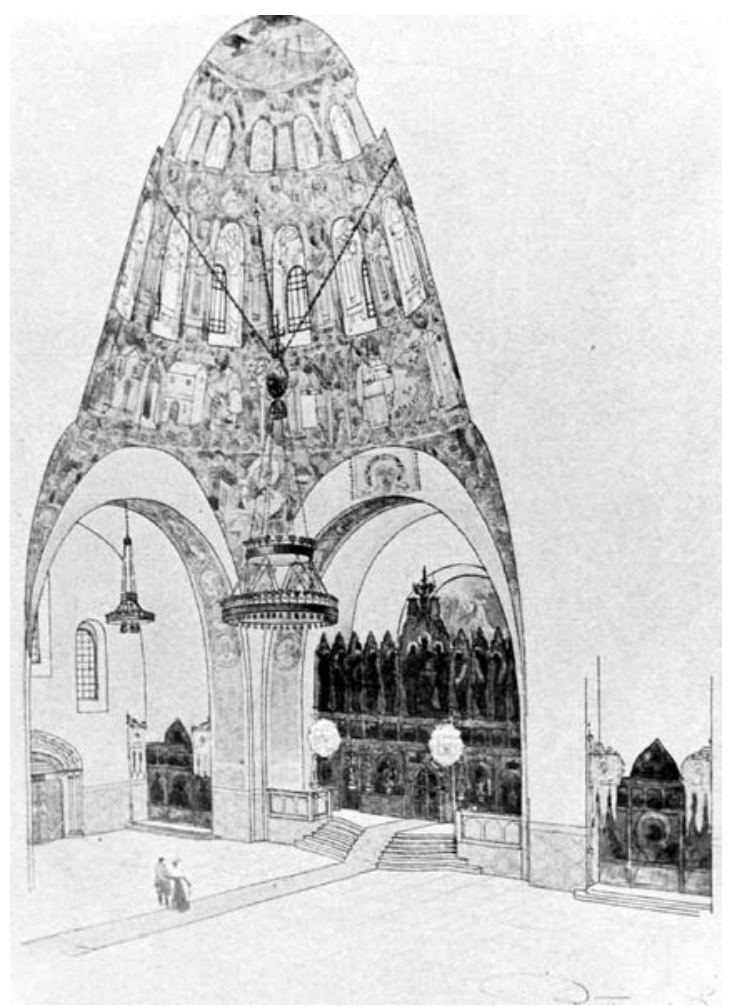

Fig. 28. Schlisselburg. Church at powder factory. Ezhegodnik Obshchestva arkhitektorov-khudozhnikov, 1906 


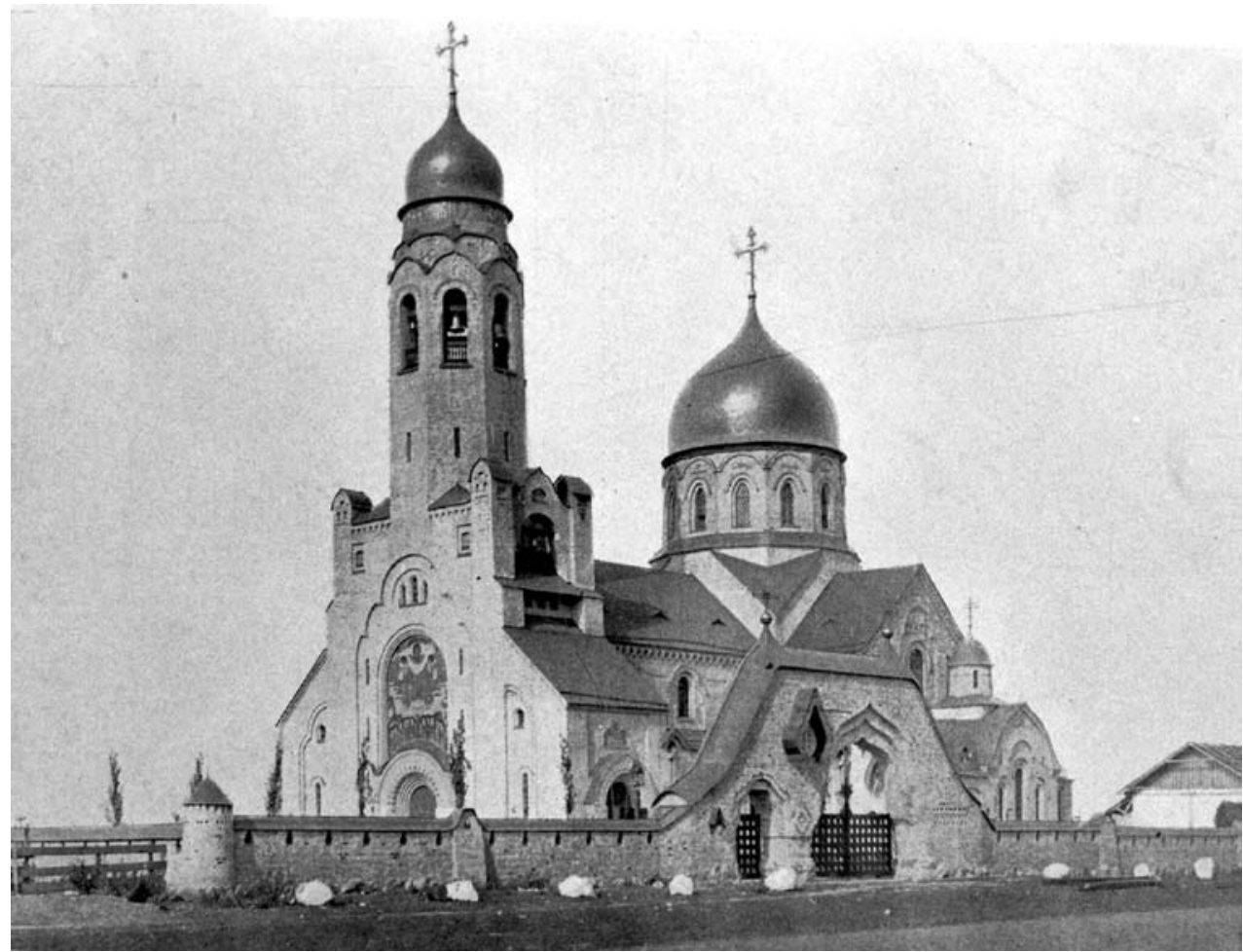

Fig. 29. Parkhomovka (near Kiev). Church of the Intercession. 1903-06. Architect: Vladimir Pokrovskii. Southwest view. Ezhegodnik Obshchestva arkhitektorov-khudozhnikov, 1908

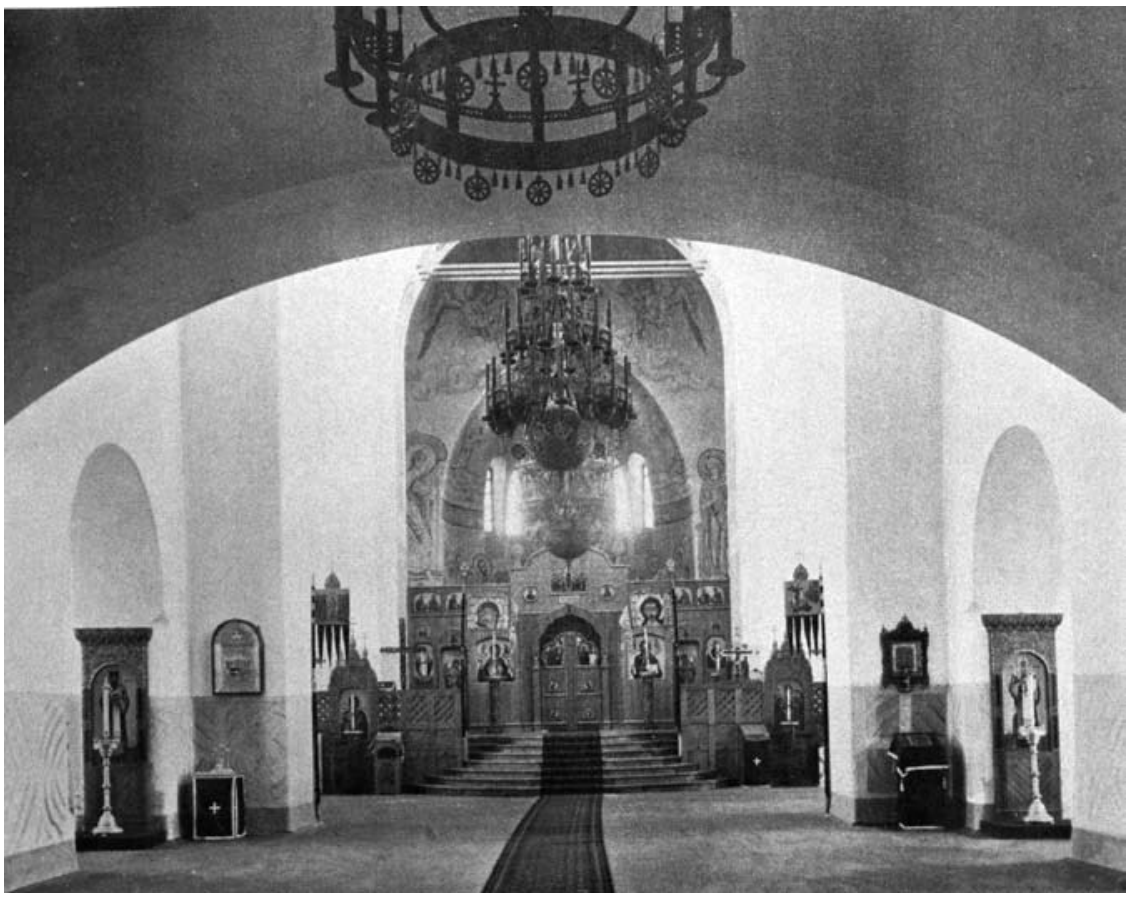

Fig. 30. Parkhomovka (near Kiev). Church of the Intercession. Interior. Ezhegodnik Obshchestva arkhitektorovkhudozhnikov, 1908 


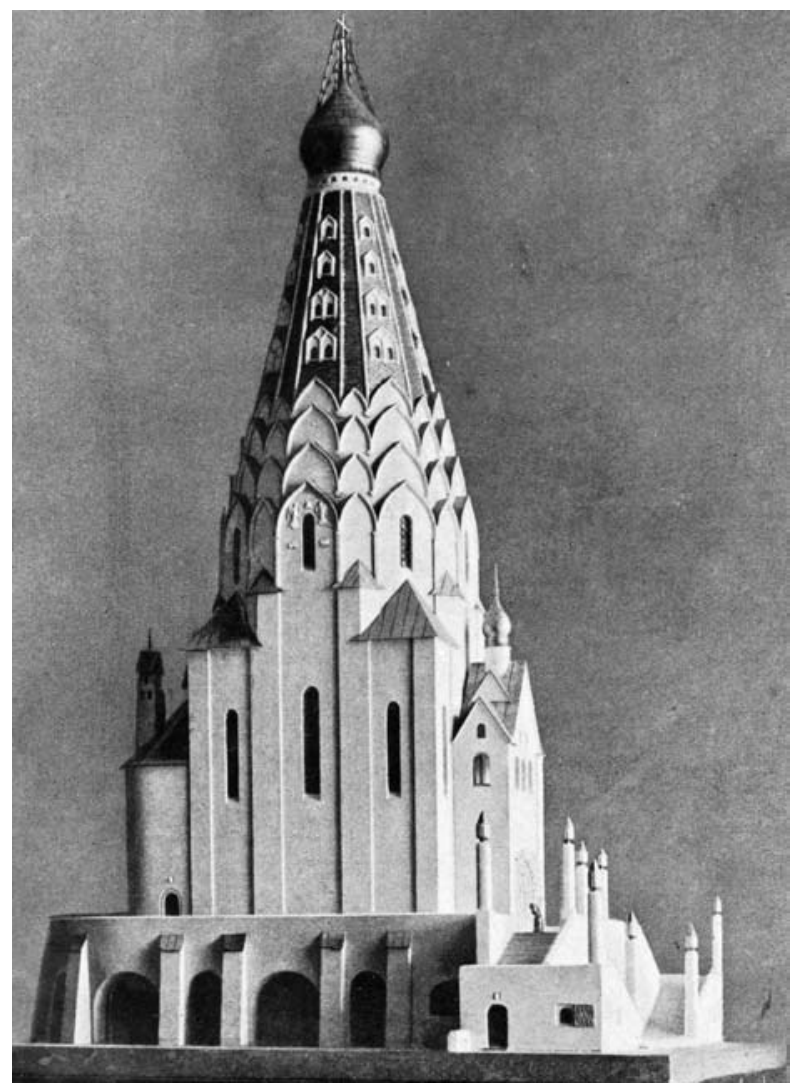

Fig. 31. Leipzig. Model of church-monument to the victory over Napoleon. 1912. Architect: Vladimir Pokrovskii. Ezhegodnik Obshchestva arkhitektorov-khudozhnikov, 1912

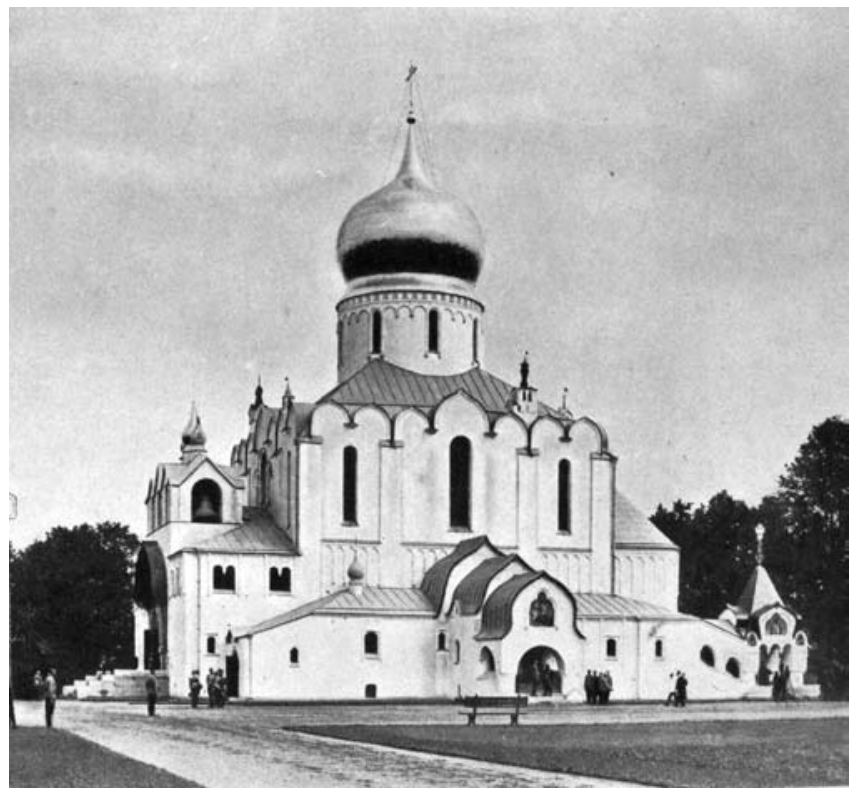

Fig. 32. Tsarskoe Selo. Cathedral of the St. Theodore Icon of the Mother of God. 1910-12. Architect: Vladimir Pokrovskii. Ezhegodnik Obshchestva arkhitektorov-khudozhnikov, 1912 
primarily to artistic and ideological concerns rather those of a religious revival. To be sure, the designs of smaller churches, including those of the Old Believer communities, achieved a balance between an aesthetic view of medieval religious architecture and the concept of the church as an active force in contemporary society.

After the revolution, many of the architects whose had defined this balance in the new style of church architecture (Shchusev, Bondarenko, Shekhtel, the Vesnins, and even Pokrovskii) resumed active careers; but by then the antireligious policies of the Soviet state had eliminated any possibility of church construction. Fortunately, one notices in publications by Russian scholars a growing interest in churches of the late imperial period; and it is to be hoped that the movement for historic preservation will expand its efforts to include these most recent examples of an old and vital architectural tradition - examples that should point the way to another revival of Russian church architecture.

1 Among the many Russian publications that examine the style moderne, two of the most comprehensive are: E. A. Borisova and T. P. Kazhdan, Russkaia arkhitektura kontsa XIX nachala XX veka (Moscow, 1971); and E. I. Kirichenko, Russkaia arkhitektura 1830-1910-kh godov (Moscow, 1978). Each of these works contains illustrations of church architecture at the turn of the century.

2 For a discussion of Ton's Russo-Byzantine church designs, see E. A. Borisova, Russkaia arkhitektura vtoroi poloviny XIX veka (Moscow, 1979), pp. 101-05 and passim; also Kirichenko, pp. 114-119 and passim.

3 A brief summary of Aplaksin's work in Petersburg is contained in V. G. Isachenko, ed., Arkhitektory-stroiteli PeterburgaPetrograda nachala XX veka (Leningrad, 1982), pp. 7-8. A detailed account of his lecture, "Russkoe tserkovnoe iskusstvo i ego sovremmenye zadachi, appeared in Zodchii, 1911, No. 3, pp. 23-24.

$4 \quad$ Zodchii, 1911, No. 3, p. 24.

5 Ibid., p. 23. It is clear that the work of Ton had a major impact on this code, particularly his standardized designs for Orthodox churches that could be reproduced with minor variations. See Borisova, p. 309.

Zodchii, 1911, No. 3, pp. 23-24.

Ibid., p. 24.

Ibid. The church statistics were provided by the office of the Procurator of the Holy Synod.

9 Ibid. In view of Aplaksin's advocacy of photography as an essential tool in the study of Russian church architecture, it should be noted that the distinguished photographer and inventor Sergei Prokudin- Gorsky lectured at this same congress on architectural monuments (churches) of the upper Volga and north Russia. Zodchii, 1911, No. 4, p. 36. The comprehensive photographing and cataloging of extant Russian churches has been resumed under the auspices of the Ministry of Culture and the All-Union Institute of Art History.

10 N. V. Polenova, Abramtsevo: vospominaniia (Moscow, 1922). See also N. V. Masalina, “Tserkov' v Abramtseve (k istorii postroiki)" in E. A. Borisova, ed., Iz istorii russkoi arkhitektury vtoroi poloviny XIX-nachala XX veka (Moscow, 1978), pp. 47-58.

11 Polenova, pp. 33-36.

12 Borisova, p. 264.

13 The letter is contained in V. V. Stasov. Pis'ma k deiateliam russkoi kul'tury (Moscow, 1967), vol. 2, pp. 58-59.

14 Photographs of the church were included in the first number of the lavishly-produced Ezhegodnik Obshchestva Arkhitektorov-Khudozhnikov (Petersburg, 1906), pp. 15 (exterior) and 116 (interior).

15 A sketch of the main facade of the projected church appeared in Arkhitekturnye motivy, 1900, No. 2, p. 27. The large scale of the design would have dwarfed its modest surroundings (cf. photograph of the extant sixteenth- century monastery church in William Brumfield, Gold in Azure: One Thousand Years of Russian Architecture (Boston, 1983), p. 152).

16 For examples of the uses of art in cultural identity, see Beverly Kean, All the Empty Palaces: The Merchant Patrons of Modern Art in Pre-Revolutionary Russia (New York, 1983); also John Bowlt, "Nikolai Ryabushinsky, Playboy of the Eastern World," Apollo, December 1983, pp. 486-93. At the same time one must note the dedication to work and enterprise that characterized the Old Believer community. Alexander Gershenkron was the first to argue for the presence of a "bourgeois ethic" among the Old Believer merchants in his Economic Backwardness in Historical Perspective (New York, 1962). While this view provides no direct explanation for a particular style of architecture in Old Believer churches, one might interpret the relatively austere design of the new churches as the expression of a sense of frugality and responsibility to the church community (obshchina).

17 "Khram Staroobriadtsev Pomorskogo soglasiia v Moskve," Zodchii, (1908), No. 48, p. 440. See also I. P. Mashkov, Putevoditel' po Moskve (Moscow, 1913), pp. 205-06. Mashkov places the cost of the church at 150,000 rubles.

18 Mashkov, p. 206. According to Mashkov the church cost "about 140,000 rubles."

19 Ibid. Cost: 70,000 rubles.

20 See description, reprinted from a pre- revolutionary source, in Moskva zlatoglavaia (Paris, 1980), p. 72.

21 "Mysli o svobode tvorchestva v religioznoi arkhitekture," Zodchii, (1905), No. 11, p. 132.

22 Ibid. 
23 Shchusev's sketch for the first variant of the khram-pamiatnik appeared in the Ezhegodnik Obshchestva ArkhitektorovKhudozhnikov, No. 1 (1906), p. 128. The revised project appeared in No. 6 (1911), p. 147. The most informative study of Shchusev's work - including the churches - is K. N. Afanas'ev, A. V. Shchusev (Moscow, 1978).

24 See description in Iu. S. Aseev, ed., Pamiatniki gradostroitel'stva i arkhitektura Ukrainskoi SSR, (Kiev, 1983-1986), vol. 4, pp. 78-80. For the Novgorod cathedrals see Brumfield, pp. 42-46.

25 Borisova and Kazhdan, p. 155.

26 Ezhegodnik moskovskogo arkhitekturnogo obshchestva, No. 3 (1912-1913), pp. 135-147.

27 See Aseev, vol. 4, pp. 113-14; also Ezhegodnik Obshchestva Arkhitektorov-Khudozhnikov, No. 10 (1915), pp. 153-59.

28 For an account of Pokryshkin's work at the Nereditsa church, one of the major historical restoration projects in Russia, see M. N. Tikhomirov, ed., Novgorod: k 1100-letiiu goroda (Moscow, 1964), pp. 194-200. The collaboration between Pokryshkin and Shchusev is extensively recounted in Afanas'ev, pp. 17-21.

29 Aseev, vol. 2, pp. 153-54.

30 See Mashkov, p. 194; also Moskva zlatoglavaia, p. 65.

31 Borisova and Kazhdan, pp. 256-57.

32 See photographs in Ezhegodnik MAO, No. 4 (1914- 1916), pp. 89-90.

33 Mashkov, p. 178

34 Ezhegodnik Obshchestva Arkhitektorov- Khudozhnikov, No. 4 (1909), pp. 55-57. See also Aseev, vol. 3, p. 288.

35 A list of church designs by the Vesnin brothers is contained in K. I. Murashkov, ed., Vesniny: Katalog- putevoditel' po fondam muzeia (Moscow, 1981), pp. 79-83.

36 A. A. Rostislavov gave a scathing critical appraisal of Parland's design in "Renessans russkoi tserkovnoi arkhitektury," Apollon, 1910, No. 7-8, p. 24.

37 For Krichinskii's own description of the ensemble, see Zodchii, 1914, No. 11, pp. 122-23. The architect gives the total cost of the monument (including special foundation work, but not interior furnishings) as 560,000 rubles. It is instructive to compare this figure with those given by Mashkov for the Moscow Old Believer churches (see above).

38 See pre-revolutionary photographs of the interior of the Kronshtadt church in Kirichenko, pp. 376-77.

39 "Molitvennyi dom staroobriadtsev," Zodchii, 1908, No. 45, pp. 418-19. The church was also extensively illustrated in Ezhegodnik Obshchestva Arkhitektorov- Khudozhnikov, 1907, pp. 54-55; 1908, pp. 51-55; 1909, pp. 51-53.

40 Kirichenko provides a survey of Pokrovskii's work in "Poiski natsional'nogo stilia v tvorchestve arkhitektora V. A. Pokrovskogo," Arkhitekturnoe nasledstvo, 1973, No. 21, pp. 69-82. His churches and project designs were frequently illustrated in the major architectural journals.

41 See photographs in Ezhegodnik Obshchestva Arkhitektorov-Khudozhnikov, No. 2 (1907), pp. 93-103.

42 See description in Aseev, I, pp. 134-35. The church was extensively photographed in Ezhegodnik Obshchestva Arkhitektorov-Khudozhnikov, No. 3 (1908), pp. 106-14. His design for the gonfalon appeared in the same journal, No. 5 (1910), pp. 105-06.

43 Project designs for the Leipzig monument were published in Zodchii, as well as Ezhegodnik Obshchestva ArkhitektorovKhudozhnikov, No. 7 (1912), pp. 104-07. The completed church was illustrated in the latter journal, No. 9 (1914), pp. 11119. What an irony to build a monument to the defeat of the country that would be Russia's major ally in a war with Germany the following year. 


\title{
Новые направления \\ в русском православном церковном зодчестве \\ начала XX века
}

\author{
У.К. Брумфильд \\ Университет Тулейн \\ Новый Орлеан, Луизиана, США
}

В начале XX века некоторые влиятельные знатоки русской архитектуры начали сомневаться в высшей степени декоративного подхода при проектировании иерквей, который царил во второй половине ХІХ века. По мнению этих архитектурных критиков, так называемая «Останкинщина» (названная в честь Церкви Святой Троицы, построенной в конце XVII века в Останкино) нарушила эстетическую чистоту средневековой русской цеерковной архитектуры и даже уменьшила духовный смысл самой церкви. В этой связи группа архитекторов, включая Алексея Щусева и Владимира Покровского, изучила новые тенденции в проектировании церквей, совмещуая изучение ранних средневековых русских архитектурных форм с новыми технологическими методами.

Ключевые слова: церковное зодчество, стиль модерн, «Останкинщина», Абрамцево, Виктор Васнецов, Федор Шехтель, Алексей Щусев, Владимир Покровский.

Научная специальность: 24.00.00 - культурология. 